\title{
The Hebrew Civilization
}

\author{
Paul TE Cusack* \\ Independent Researcher, Canada \\ *Corresponding author: Paul TE Cusack, Independent Researcher, DULE, 1641 Sandy Point Rd, Saint John, NB, Canada E2K 5E8, Canada
}

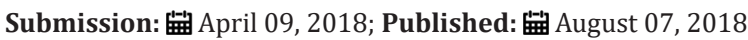

\begin{abstract}
Here is a paper that outlines possible connections between the Egyptian, the Ten Commandments, Stone Henge, and St Columba's Psalter. The key is the Mathematics knows at the time by the Egyptians. The Hebrews picked it up from the time they were in Egypt. Then, as the Lost Tribes migrated toward the British Isles, they brought the knowledge with them encasing it in the Psalter and Stone Henge.
\end{abstract}

\section{The Hebrews}

Does civilization follow the Hebrews or does civilization follow the Hebrews? Perhaps this question can't be answered conclusively, but what can be demonstrated with modern methods of analysis is that whoever they went, they took what they learned with them. We know from Biblical sources, now backed up by genetic evidence that Abraham came from Ur in modern day Kuwait in ancient Persia. He had a son Issac, a promised son, whom God asked to be sacrificed like a Lamb on an altar. As the story goes, Abraham was stopped by the angle of God just before Abraham was to kill his only son. This foreshadows of how Jesus, 1800 years later was the Lamb of God who takes away the sins of the world was sacrificed upon the cross as we all know. Some believe Jesus was God; others believe he was another important prophet. That discussion will not take place here, but will be taken up is to show how the Israelites influenced civilization wherever they went.

\section{Egypt}

From the Biblical account in the book of Genesis, the Hebrew people ended up in slavery in Egypt because they were starving in a famine. Abraham's grandson Jacob, whose name was later changed to Israel, had 12 boys. Two of these were royal according to the biblical account: Judah and Joseph. As the story goes, Joseph told his brothers, including Judah, from whom David and thus Jesus descends, would bow down and worship him. His brothers were so angry at the prospect, they decided to sell him into slavery into Egypt.Joseph ended up in jail under the accusation that he tried to rape the pharaoh's wife. When it was discovered that Joseph was an interpreter of dreams, the pharaoh put him second in charge of the Kingdom. Meanwhile there was a famine in the land of Cana. The 11 remaining sons of Israel (Jacob) travelled to Egypt to buy grain. Joseph recognized his brothers, but Hui brothers did recognize him. After a successful ploy by Joseph, his brothers and father were reunited in Egypt. The Israelites stayed in Egypt for 4000 years until Moses, a Hebrew raised in the Pharaoh's household, decided to lead his people out of slavery to a land of their own, modern day Israel.

Moses would have had the full education of the Egyptian Sciences and Mathematics. Their math and physics was far more advanced than previously thought by modern scholars. For example, they knew the quadratic equation, the golden mean, the energy parabola - facts which hither to were not known to modern times. The Egyptians build these mathematical acts into their famous pyramids.The Hebrews conquered the land of the Phillistines (Palestine). Their land was conquered in 586 BCE by the Babylonians. The Hebrew was taken captive in Babylon until they were released 70myears later by Cyrus.

\section{Arc of the Covenant on Crete}

The most important thing for the Hebrews was the Ark of the Covenant. The covenant was a one sided promise by God who gave the Hebrews the 10 Commandments, hitherto lost. The author has found then, decoded them from what were called the un-decoded Minoan tablets. They are actually the Hebrew 10 Commandments and explanations of those commandments on half a dozen other "Minoan tables" from Crete. I suspect the most prized possession of the Jews were these 10 commandment tablets. They must have secretly sent them to Crete for safety where Israel was taken captive in the Babylonian captivity in the $6^{\text {th }}$ century BCE.

When the 10 Northern tribes left Israel, it was unknown hitherto where they went. We now know, from genetic testing, that the Israelites went to mainly Ireland, Scotland, and Wales. Milieus carried the YDNA of David from Jewish Khazaria in modern Kazakhstan to Egypt then on to Ireland through his 8 sons, 3 of whom survived, Ire, Hebert, and Hermon. They went on to found 
the royal O'Brien's in Munster commonly called the L226 Irish Type III's or the Dalcassians (part of cases.) In addition, the French throne was founded by an Israelite as the people of Gaul wanted a King. They sent to Israel for a royal king of the royal house of Israel. He therefor too is an L226.Modern genetics is showing that the Hebrews travelled to Wales, Scotland and Munster Ireland. Interesting that this is where we find a conglomeration of the stone circles, simpler but similar to Stone Henge. The geometry of the Egyptian are built into these archaeological sites.

\section{ST Columba}

He was a descendant of a Minster King. The Kings of Munster are the 0`Briens mainly but have other surnames or clans as well. St Columba, a script writer, must have known the ancient Egyptian and Hebrew mathematics, science, language and religions of these related peoples. St Columba encoded this knowledge in his famous Psalter or prayer book. The rest of this paper is the illustrations provided to how the reader how the Pyramids, Stone Henge, the Minoan tablets and the Psalter all fit together in a continuous story from Abraham of 1800 BCE until today with the lineage of the ancient regime residing in the person of this author.

\section{Pyramids}

I was looking at a book entitled "Decoding the Pyramids." It is evident that these ancient people possibly knew about the physics contained in this blog. For example, the Chephen" pyramid is $143.5 \mathrm{~m}$ high. That of course is 0.866 . The site takes up 13 acres, whereas we have 13 cycles of time. The blocks a either 2 or $1 / 2$ tones. $g=2$ and $t=1 / 2$ at minimum energy. The angle of the four sided pyramid ( 4 dimensions $\times 3$ pyramids $=12$ dimensions) is 52 degrees. I would have liked to have seen this as $\mathbf{5 7 . 2 9}$ degrees. The pyramids are all on the western side or the right hand side of the Nile. Judgement Matthew 25. Now the layout of the pyramids is in the form of a parabola. The major pyramid is at the apex of the parabola when Jesus came. For someone interested, there is a gold mine of things to be discovered.

Now there are also pyramids in Russia, and there are in Myian territory as well. The North American Indians were the tribe of Manasseh. The 10 Northern tribes migrated to Kazakhstan. And of course the Israelites were in Egypt as well. Perhaps the Israelite s learned the secrets from Egypt, and brought them to Russia and Mexico. Even the location in Egypt is 30 degrees longitude by 30 lattitude. This is the cross of sin and cos. St Columba went to Scotland. We know from genetics that the Israelites populated Scotland. His Psalter holds the same keys. The Myian calendar said the world would change ion Dec 21, 2015. But the Christian calendar is off by 3 years. So Christmas 2015 looks like the date for the coming of Jesus. I've calculated the same date two other distinct ways. If someone were interested, you could write a book. I'd do it but I'm too busy starving to death. I would check the Arc of the covenant too. It probably encodes the C.U.E. as well. Boy are we modern s arrogant!

The Great Pyramid's base is 2. The Chephen is also 2. And the Pyramid of Menakure is $1 / 2$ This encodes the formula

$1 / \mathrm{G}=\mathrm{M}$ rho/E rho $(\mathrm{dM} / \mathrm{dt})$

$1 / 2=1 / 4^{*}(2)$

(Figure 1)

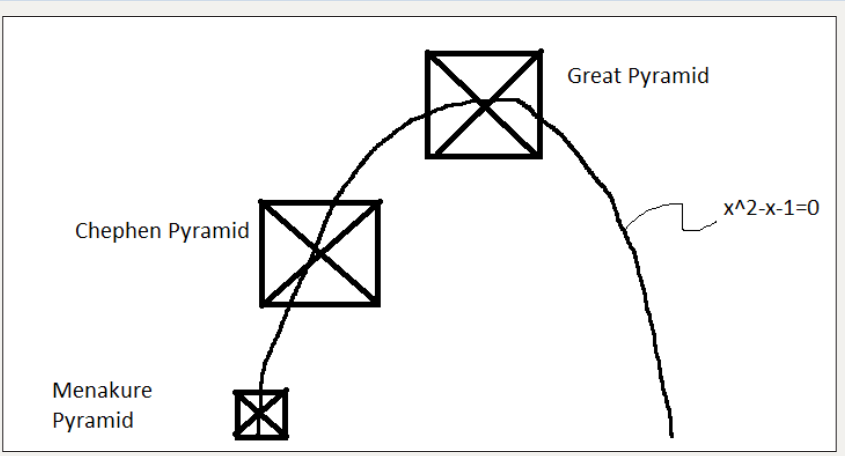

Figure 1:

How about this:

The peak of the pyramids lie on the energy parabola. And the size of the pyramid is proportional to the derivative. $\mathrm{dE} / \mathrm{dt}=2 \mathrm{t}-1$

at $\mathrm{t}=0$

$2(0)-1=-1$

$\mathrm{att}=1.5$

$2(1.5)-1=2$

(Figure 2)

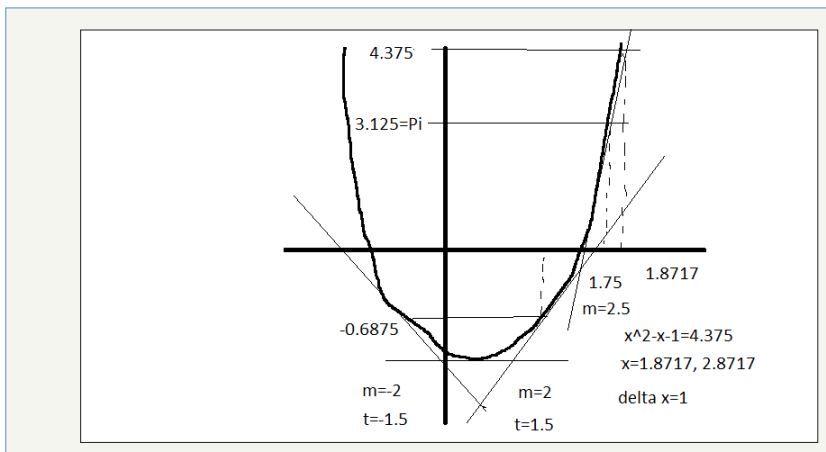

Figure 2: 
The Ark of the Covenant is $1.5 \times 1.5 \times 2.5$

The slope $m=2,-2$ at $t=1.5,-1.5$ $\mathrm{m}=2.5$ at $\mathrm{t}=3.125$ or $\sim \mathrm{Pi}$

The Pyramids encode the Energy Parabola known to the ancients (Figure 3).

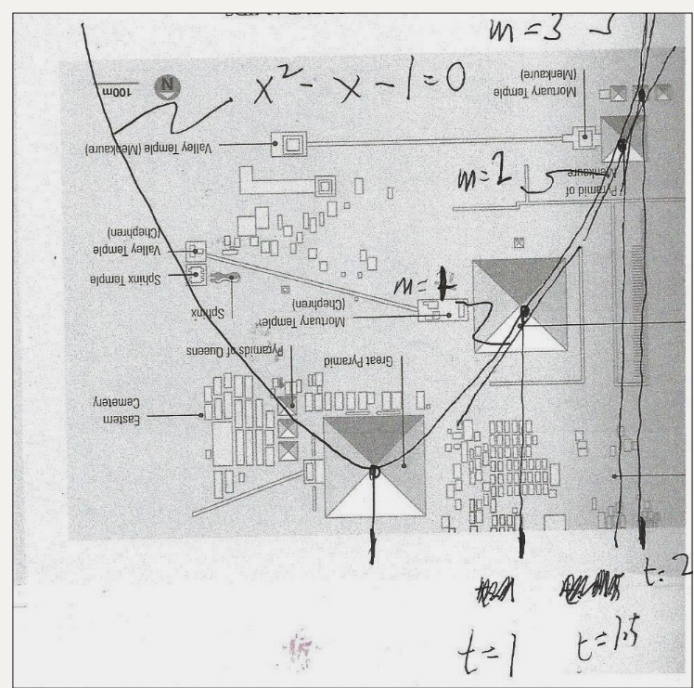

Figure 3: This illustration of the plan of the pyramids was taken from decoding the pyramids. I've sketched on top of it the energy parabola. Obviously those who built the pyramids (the Israelites?) knew the energy parabola.

It was the Egyptians who had all this mathematical physics. They had log, fractions (golden section), algebra and the quadratic equation which solves the following equation

\section{$\mathrm{X}=1 /[\mathrm{X}-1] \quad \mathrm{X}=1.618$}

or

$x^{\wedge} 2-x-1=0$

$3763 \mathrm{BC}-500=3263$

1/0.3263=3.064 (Figure 4).

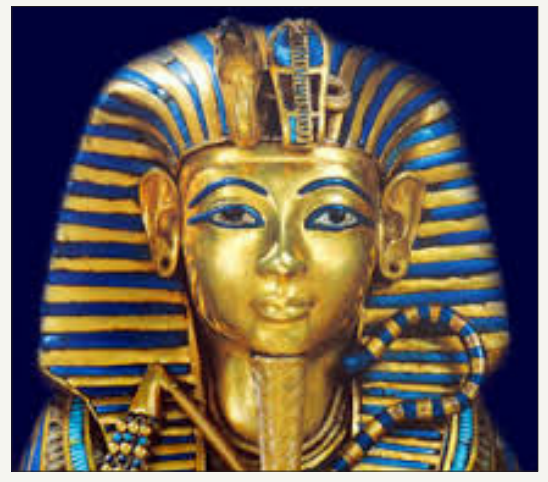

Figure 4:

What Mathematical Physics the Ancient Knew and We Didn't, and How They Expressed It

The author undertook an investigation in area of Mathematical Physics on the origin of the universe. My goal was to derive the universal equation-the Holy Grail of Physics for the last 300 years. The reason the pyramids and Stonehenge could not be interpreted is that modern science did not know as much physics as the Ancient Egyptians / Hebrews knew. From my blog on Physics, one can see all the physics that was lost to the ages. Stonehenge and the pyramids go together. The same people were behind both. They stand together. I discovered in my work that the Egyptians already knew the universal energy equation. In fact it is embedded into the very geometry of the Pyramids, the highest achievement of their civilization. It is interesting that these ideas were known to other cultures that most likely learned it from Egyptians. They include: The Hebrews, the Scottish Jews, the Irish royalty, St Columbia, and the Mayans. Nostradamus even picked up on it in his quatrains. In this brief paper, I intend to show what the ancient Egyptians knew and how it spread throughout the world.

\section{Egyptians mathematics}

In my investigation of Physics, I derived the Cusack Universal Energy Equation C.U.E.E. It is a polynomial as follows:

$x^{\wedge} 2-x-1=0$

This is quadratic equations which were known to the Egyptian Mathematicians. It is solved by the well know equation:

$\mathrm{X}=-\mathrm{b}+/-\left[\operatorname{sqrt}\left(\mathrm{b}^{\wedge} 2-4 \mathrm{ac}\right)\right] / 2 \mathrm{a}$

If one plugs $a=-1, b=c=-1$

We get the solution of what is called the Golden Mean, or $\mathrm{x}=1.618$

The above polynomial is also expressed identically as

$\mathrm{x}=1 /[\mathrm{x}-1]$

$x(x-1)=1$ 
$x^{\wedge} 2-x-1=0$

1.618 is the only number that solves this equation.

This, then is the U.C.E.E (Figure 5).

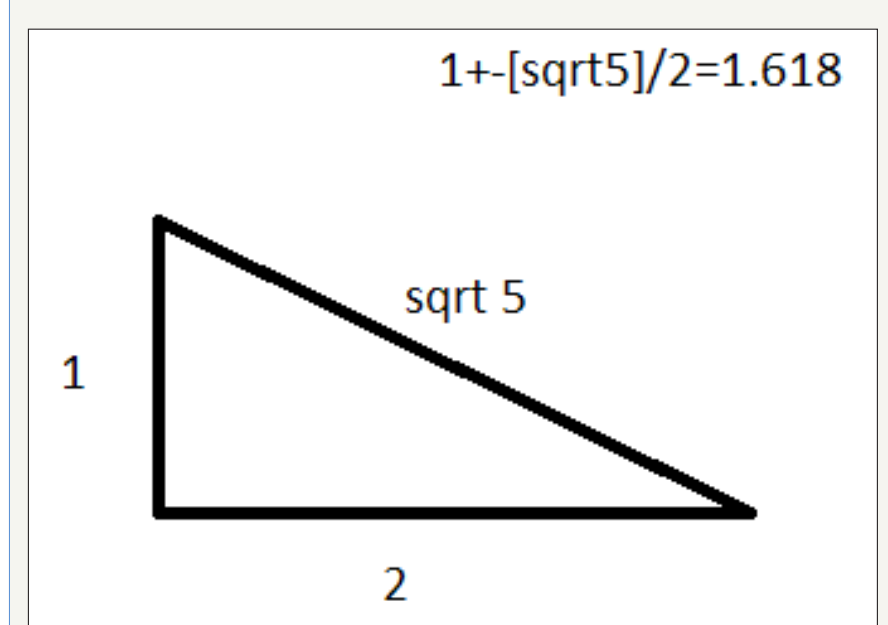

Figure 5: The Golden Mean is encompassed in geometry of a right triangle as follows.

Note that the Golden Mean=1.618=1+/-[ sqrt 5]/2 This is simply the Quadratic Equation with $\mathrm{a}=1, \mathrm{~b}=\mathrm{c}=-1$

$$
\begin{aligned}
& x=-b+/-\operatorname{sqrt}\left(-b^{\wedge} 2\right)-4(a)(c) / 2(a) \\
& =1.618=1+/-[\text { sqrt } 5]
\end{aligned}
$$

The Egyptian Mathematicians also knew Trigonometry which relates the length of the sides of a right triangle by sine, cosine, and tangent. We know this because the geometry of the Pyramids requires knowledge of these facts. Also, they knew Pythagoras' theorem $a^{\wedge} 2+b^{\wedge} 2=c^{\wedge} 2$ for a right triangle. Did the Egyptians know Calculus? Calculus is supposedly discovered by Sir Isaac Newton. But the knowledge of the C.U.E.E. is called a parabola. The derivative involves the derivation of the rate of change of the function in another function. The derivative of the polynomial $x^{\wedge} 2-x-1=0$ is $2 x-$ $1=0$.

I suggest the ancient Egyptian may have known calculus since they knew the quadratic equation and parabolas. Interesting that comets in Astronomy follow a parabola.A quirk of calculus is that the derivative of the function $e^{\wedge} x=e^{\wedge} x$. Another quirk is that the derivative of the $\sin x=\cos x$. These functions are paramount in the C.U.E.E as $y=y^{\prime}$ or the derivative equals the function. The universe is described by the cosine in series form. It is the famous Kepler function: $\mathrm{E}$-esinE=M, This is a parabola too.

\section{Egyptian architecture}

In the great Pyramid, the trigonometry involves the golden mean. Someone has produced this interesting graphic: (Note the golden mean) (Figure 6). Now, in "Decoding the Pyramids", the author provides a plan view to scale of the Pyramids at Giza. They are laid out in plain view to follow the C.U.E $>E$ (Figure 7). Here it is in Figure 8. If you lay one over the other, for the Great Pyramid, $t=0.9$ or (900-
$500=400 \mathrm{BC}$ ) years before Christ. $\mathrm{Y}=1=$ Energy Alexander the Great conquered Egypt in this period. Ptolemy was made Pharaoh. Doing the same for the Chephren Pyramid is at 1.85 (1850-500)=1350 King Tut became Pharaoh. The third pyramid lies at 2.5375 or 2037 $\mathrm{BC}$, end of the old Kingdom (Figure 9).

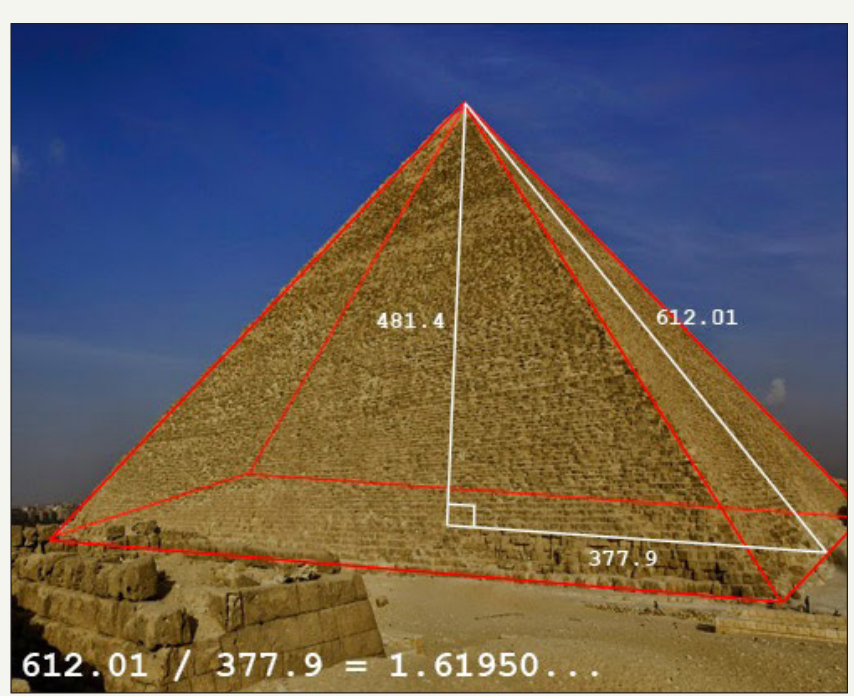

Figure 6: From Internet: Images of the Pyramids.

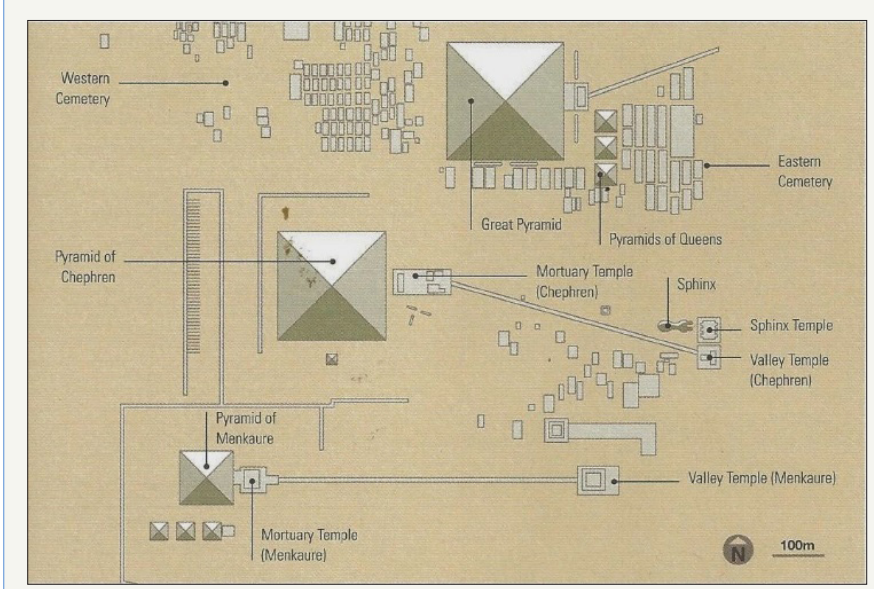

Figure 7: Decoding the Pyramids.

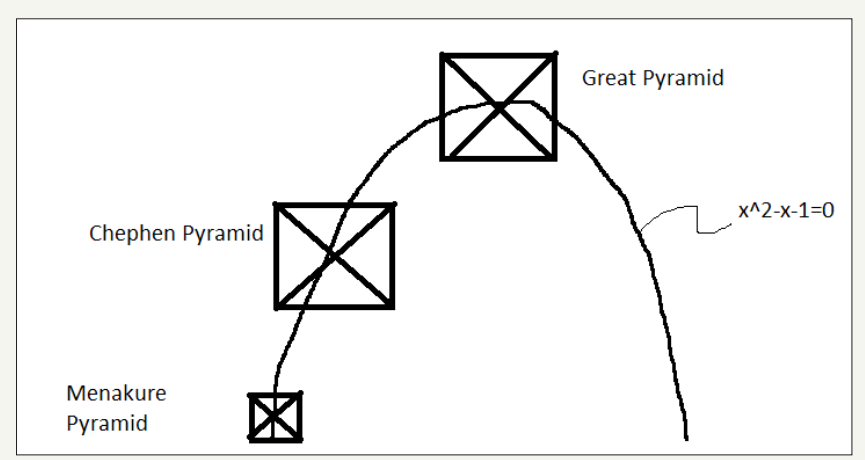

Figure 8: 


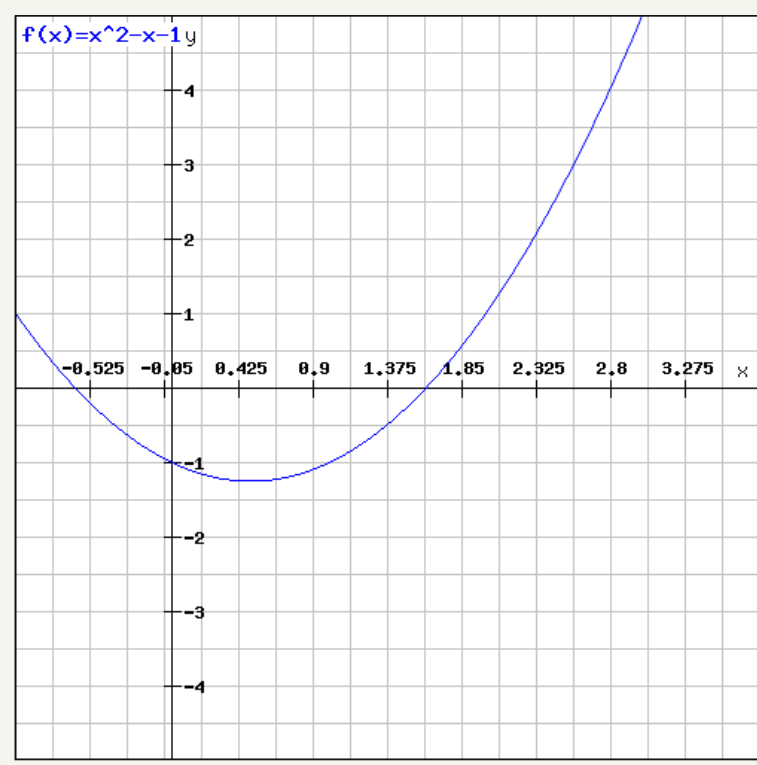

Figure 9: Even more interesting is that if time is the $\mathrm{x}$ axis, there is a spacing of the pyramids that lead to.

Continuing, the area of the great Pyramid is 13 acres. Without going into all the Mathematical Physics (which is available on my blog Astrotheology the Missing Link), there are 13 cycles of time in the universe. Finally, according to the scale drawing, the Pyramids have the length of the legs of $1,2,2$. This embodies the golden mean: $1+2+2=5, \& 1,2$ from above. The Pyramids are shown in "Decoding the Pyramids", to lie at 30 longitude and 30 degrees latitude. From Pythagoras' Theorem, the hypotenuse is 4.242 . This is very close to $\mathrm{Pi}-\mathrm{e}=3.1415-2.71828=0.4233=$ cuz. This is a physical constant in our universe, not revealed until now. It was sometimes called Einstein's constant.

Israelites: It is a Historical fact that the Hebrews spent 450 years in Egypt before being lead out of slavery by Moses. I think they took this universal geometric knowledge with them that they must have learned in Egypt (Figure 10). The Ark of the Covenant is $1.5 \times 1.5 \times 2.5$. The slope $\mathrm{m}=2,-2$ at $\mathrm{t}=1.5,-1.5 . \mathrm{m}=2.5$ at $\mathrm{t}=3.125$ or $\sim \mathrm{Pi}$. The Pyramids encode the Energy Parabola known to the ancients. This indicates the Egyptian Mathematicians knew elementary calculus. The slopes of those tangents are derivatives of the C.U.E.E

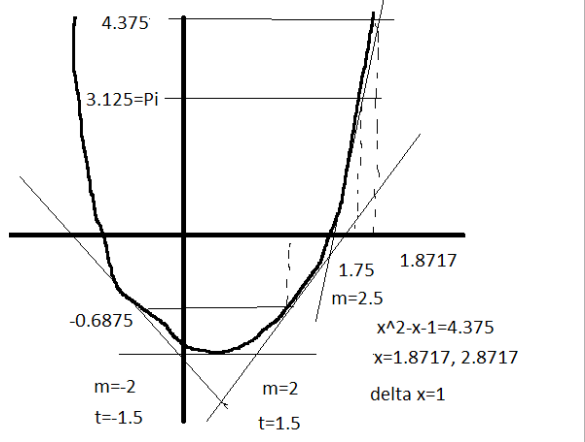

Figure 10: The arc of the covenant so well described in the Hebrew Scriptures, has the dimensions, $1.5 \times 1.5 \times 2.5$.

\section{Egyptian pyramids}

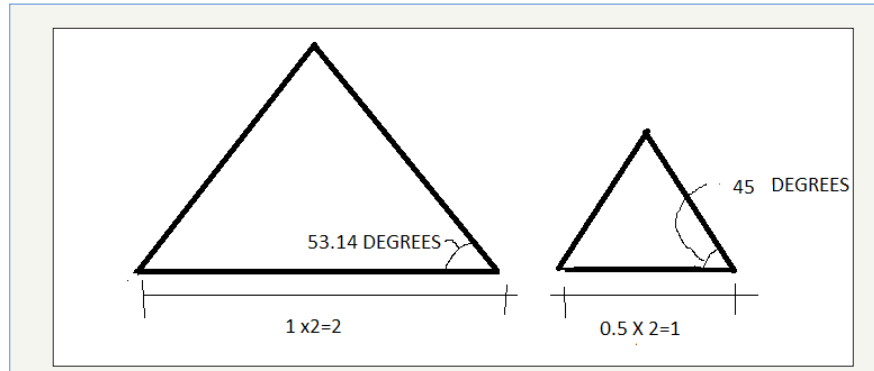

Figure 11: the pyramid of khafre.

The Pyramid of Khafre: The angle that each face of this pyramid makes with its base is $53^{\circ} 10^{\prime}$ (Figure 11). The inverse slope of each edge turns out to be 1.059250 . This number is approximately $1+1 / 17$ (accurate to about $0.04 \%$ ). The inverseslope of each face of this pyramid is approximately $3 / 4$. The seked is 5 palms, one finger/cubit. But, based on Lehner's data, the accuracy is not nearly as good as for the Great Pyramid. (It's accurate to about $0.13 \%$.) Cusack's Model of the Universe POINT $(0.5,0)$,

Line $\mathrm{Y}=\mathrm{OX}+1$,

Parabola X^2-X-1,

Polynomial $\mathrm{X}=4 / 3 \mathrm{PiR}^{\wedge} 3$

(Figure 12\&13)

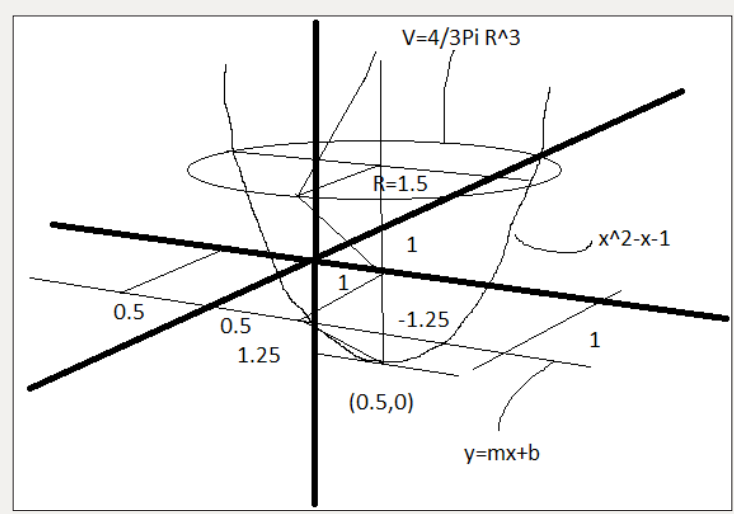

Figure 12: the Egyptians knew. The orbs told them. 


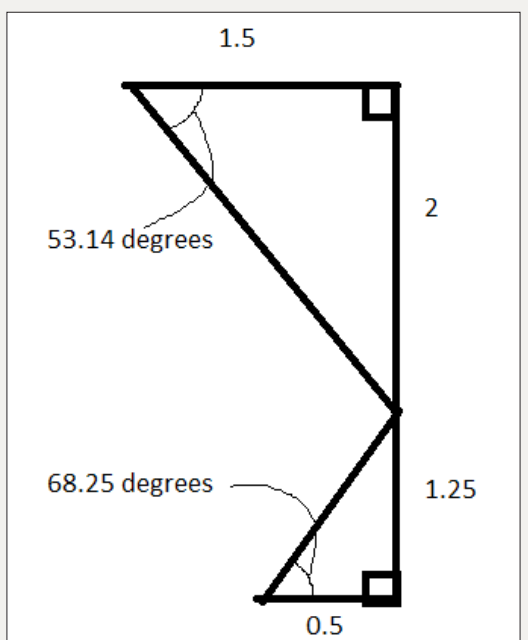

Figure 13:

\section{Ten Commandments}

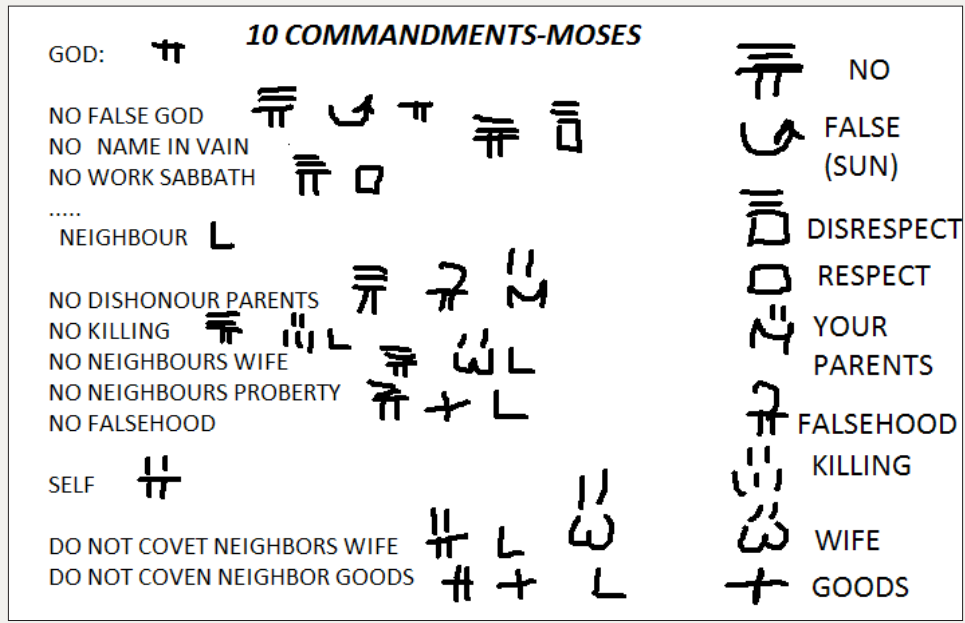

Figure 14:

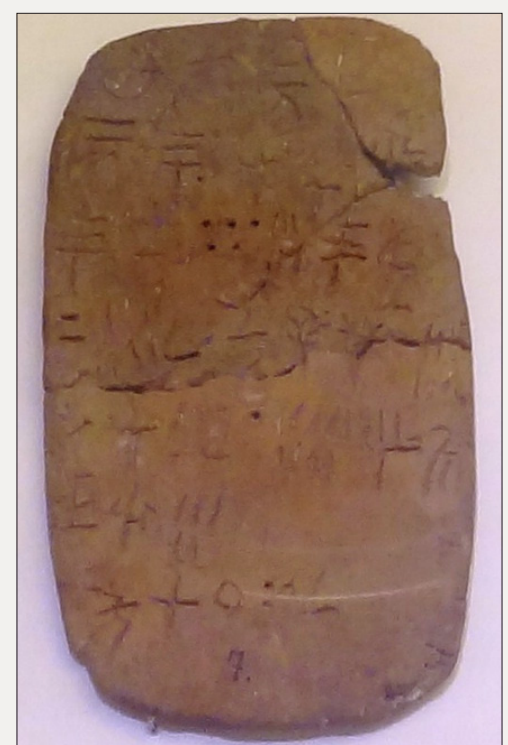

Figure 15: 


UNGODLY GOD

Figure 16: Because it is Hebrew it is read left to right. Symbols are used to represent nouns or concepts. There are other symbols I can't make out because of poor eyesight. But I think this is the Decalogue of

Moses 1200 BCE.

\section{Moses' 10 Commandments 1200 BCE (Figure 14-16)}

Adolf Hitler became interested in acquiring the Ark in order to achieve world domination. In 1936, when US agents Colonel Musgrove and Major Eaton discovered this, they sent Indiana Jones on a mission to find the Ark before the Nazis. Though he did find the Ark first, it was later stolen by Nazis nonetheless. The Ark changed hands between Indy and the Nazis several times before the Nazis took the Ark to a secret island base near Crete. The reason there are 5 holes and 2 holes is that there are 3 commandments that have to do with God, 5 have to do with neighbour and 2 have to do with self. The holes appear in the correct location, just prior to the commandments. There are 5 holes, 1 hole and 2 holes. The Egyptians (and Hebrews) knew [1+sqrt 5]/2=1.618 = Golden
Mean. $\mathrm{x}=1 /[\mathrm{x}-1]$ (See my blog on Astrotheology. The Missing Link for more information), it encoded into the pyramids. On August 7, the last line of the tablet looks to me like a backward Sigma=Sum or Add. The horizontal line through it represents don't add. The next symbol is already defined as property. $O$ might be God and L is neighbour. So it reads, "Don't add properties of God to Neighbour".

\section{Honourable women tablet}

Minonan" Tablets" Actually Hebrew Tablets Marriage To A Woman Who Is Not Property (Figure 17). Women Have Honor In Having A Fe-Tus' Who Are Not Sinful Kids.(Yid Is A Period) INSIDE CLOCKWISE From The Yid: Women Who Are Property Have Kids That Sin. Murder, No Adultery, Falsehood (P/F)And Stealing (Sh) In The Middle, Right To Left: Do Not Covet Women / Calf.

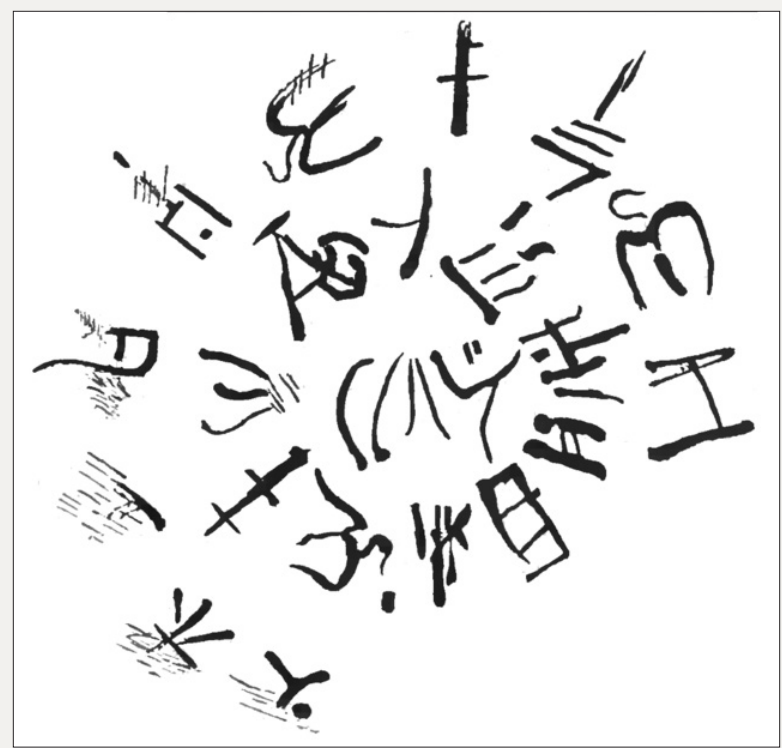

Figure 17: As read from the outside counter clock wise. it goes something like this. It is Hebrew. The bottom of the symbol or letter lies inward toward the centre of the circle (except for the symbol of women like a "w" or breasts.)

\section{$9^{\text {th }} \& 10^{\text {th }}$ - Coveting tablet}

Line 1: A Divided God of Female Fertility Gods. Is the Property of Evil Children?
Line 2: Do Not Covet Property.

Line 3: Do Not Covert Stolen Property/ Do Not Murder The Property of our Neighbor's Wife. 
Line 4: Do Not Add Properties of False Gods.

Line 5: Do Not Cover Uncircumcised Slave (Figure 18).

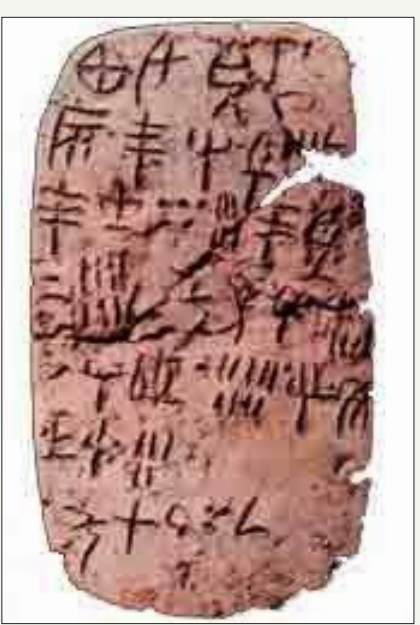

Figure 18:

\section{$5^{\text {th }}$-Murder tablet}

5 Vertical Lines Are Murder. It Is The $5^{\text {Th }}$ Commandment.

Line 1: Babies/Murder during War.

Line 2: War/Murder Married Woman (Wife).

Line 3: Family/Murder Is A Necessary Evil/Don't Murder The Unborn Fetus (Figure 19).

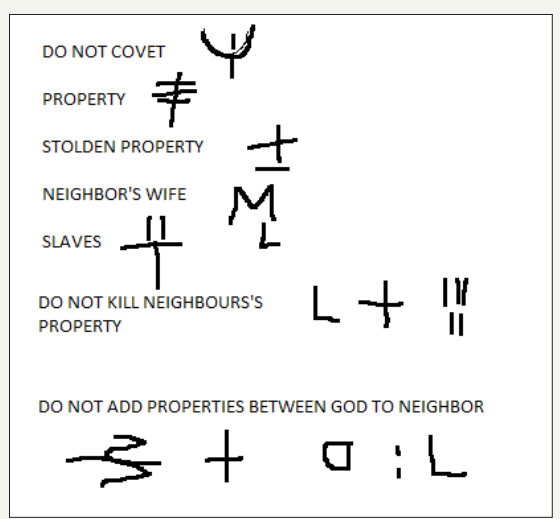

Figure 19:

\section{$7^{\text {Th }}$-Stealing tablet}

False $=$ Stolen

Line 1: Neighbour's False Property.

Line 2: False Children.

Line 3: False Wife.

Line 4: False Honour.

Line 5: False Slave.

Line 6: False Calf (Figure 20\&21)

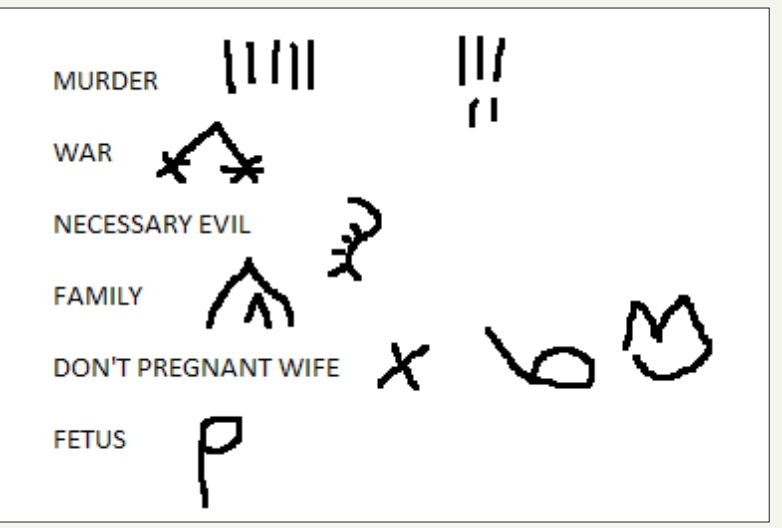

Figure 20:

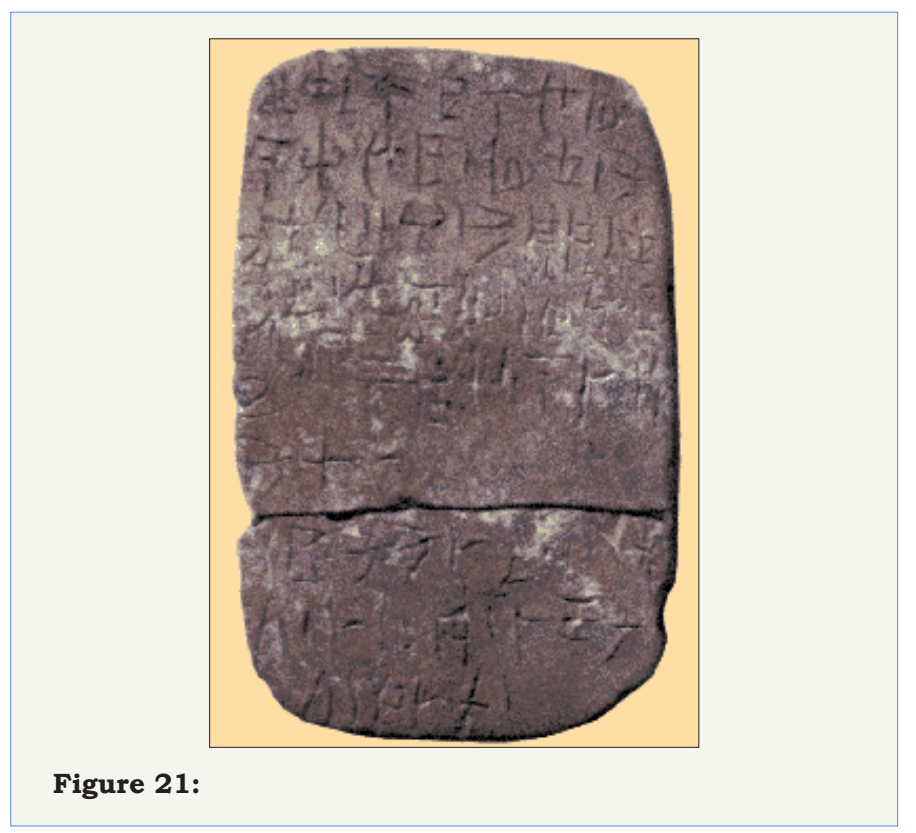

\section{$6^{\text {th }}$-Adultry tablet}

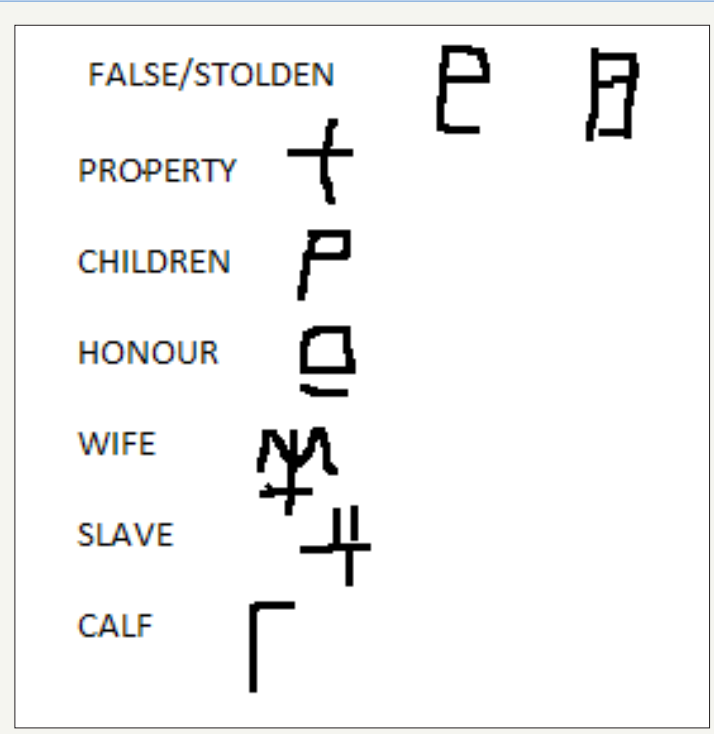

Figure 22: 
(Figure 22)

Line 1: What is Holy and Sinful, It is Sinful to have the property of illegitimate sinful marriages to your neighbor (mixed marriages).

Line 2: It is sinful to have the property of sinners who worship unholy, false fertility gods (fertility gods).

Line 3: Holy uncircumcised illegitimate children have the property of illegitimate evil children of adultery (fornication).
Line 4: It is a property of sinful evil children of a divided god who are sinful adultery who masturbate without neighbor (masturbation).

Line 5: Children are sinful or not sinful of illegitimate adultery (Adultery).

Line 6: It is forbidden by god and sinful for two men (Homosexuality) (Figure 23)

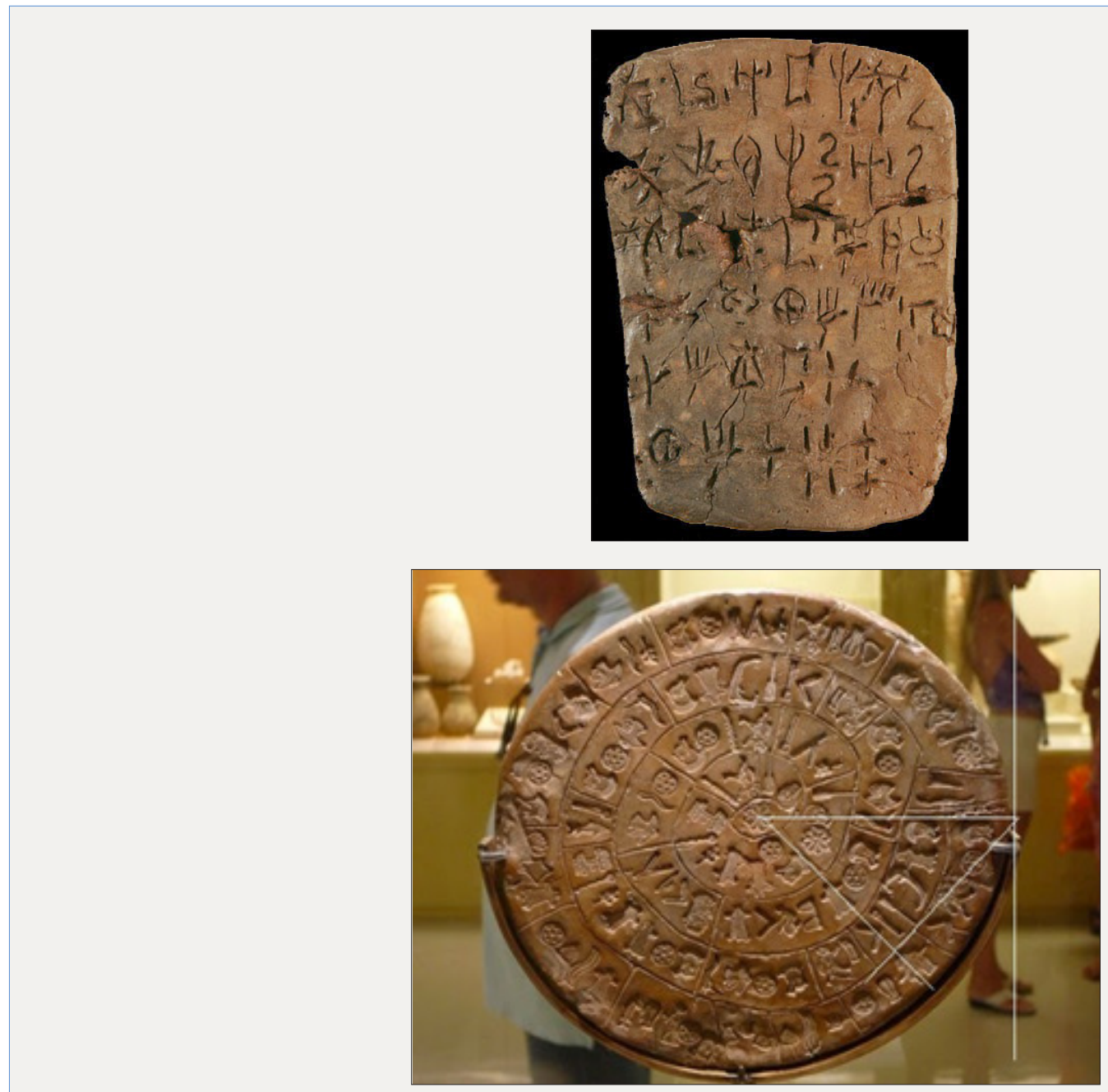

Figure 23: It is forbidden by god and sinful for two men (homosexuality).

$y=e^{\wedge} x=y^{\prime}$

the radius $=6.67=\mathrm{G}=\mathrm{d} 2 \mathrm{E} / \mathrm{dt} 2$

$1=$ centre

8 pedals on the flower.

$\mathrm{D} 2 \mathrm{E} / \mathrm{dt} 2-\mathrm{E}=\mathrm{Ln} \mathrm{t}$

Integral $\mathrm{dE} 2 / \mathrm{dt} 2+$ Integral $\mathrm{E}=0+\mathrm{C}$

$\mathrm{E}+1 / 2 * 1 / 3$

$\mathrm{E}^{\wedge} 3=\mathrm{C}$

$1^{\wedge} 3 / 6=\mathrm{C}-1$
$\mathrm{C}=0.8333$

$1 / \mathrm{e}^{\wedge} 0.1667=0.8465 \sim \sin 1=\cos 1$

DTheta $/ \mathrm{dt}=3=\mathrm{c}=$ omega .

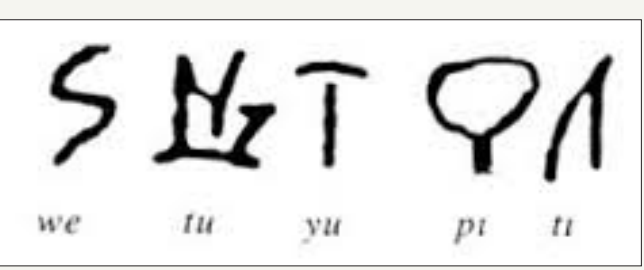

Figure 24: Sinful marriages have the property of male and female fertility gods and goddesses. 
Sinful marriages have the property of male and female fertility gods and goddesses (Figure 24).

Hebrew is the basis of European languages. It leads to the Greek alphabet which lead to our modern alphabet. Words like Shin=Sin and $\mathrm{M}=$ Marriage. $\mathrm{Fe}=$ Fetus and $\mathrm{S}=\mathrm{Sin}, \mathrm{Pi}=\mathrm{P}=\mathrm{Pharaoh}=\mathrm{God}$. You can decode the remainder. Should be an interesting story.

\section{$4^{\text {th }}$-The marriage tablet}

I've decodedthis one too

Line 1: Having a dis-honourable marriage is not a marriage. No honour children are illegitimate.
Line 2: Having a fertility god is no god.

Line 3: Anunlawful marriage is false and sinful.

Line 4: An unknown god is having no honor/a fertility god is having uncircumcised (having the property of) evil children.

Line 5: Divided god is a marriage of a sinful unlawful marriage.

Line 6?

Line $7 ?$

Line 8: ----- (Figure 25 \& 26)

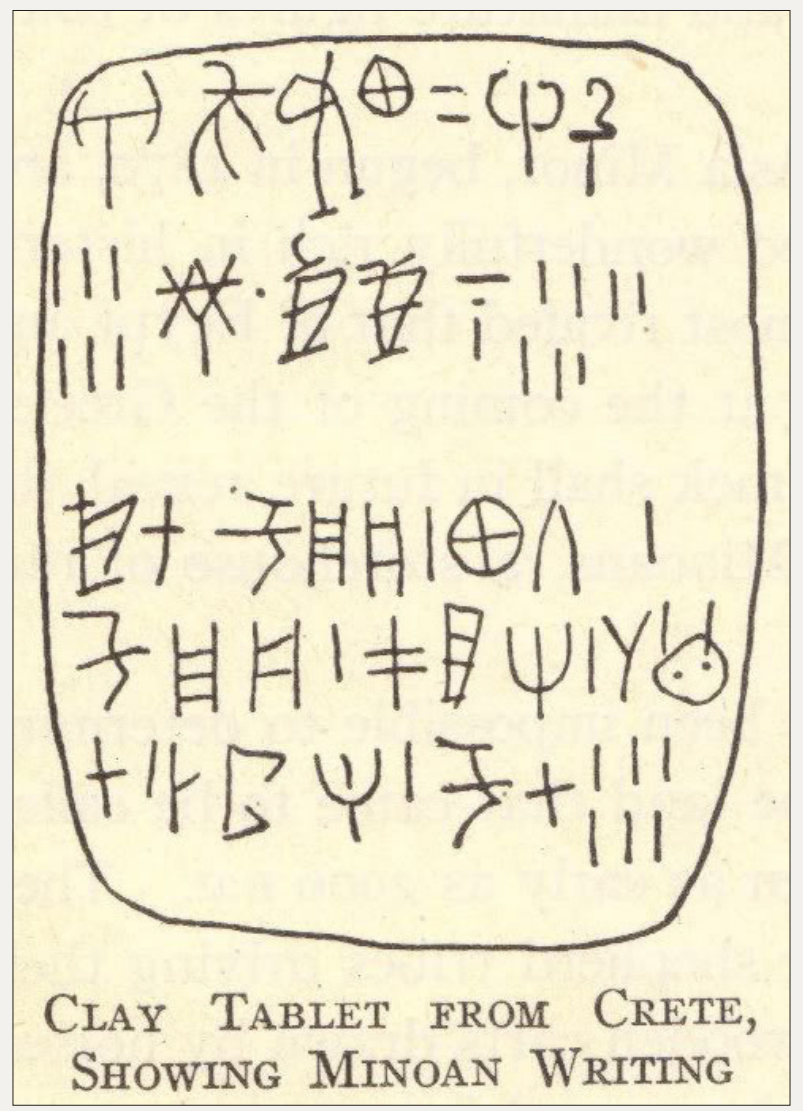

Figure 25:

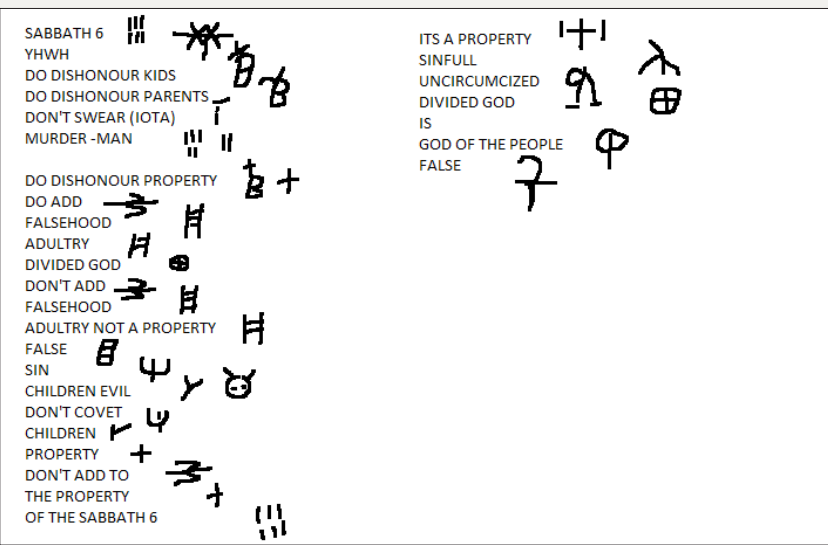

Figure 26: 


\section{Commandments-YHWH tablet}

Line1: Have no false god. It's a sinful property of the uncircumcised to have a divided god Line2: Keep holy (YHWH) the 6 (Sabbath)/do not dishonour your kids/do not dishonour you parents/don't murder.
Line 3: Do dishonourproperty/ don't add falsehood and adultery/don't have a divided god Line 4: Don't add falsehood and adultery/property of false sinful children of evil.

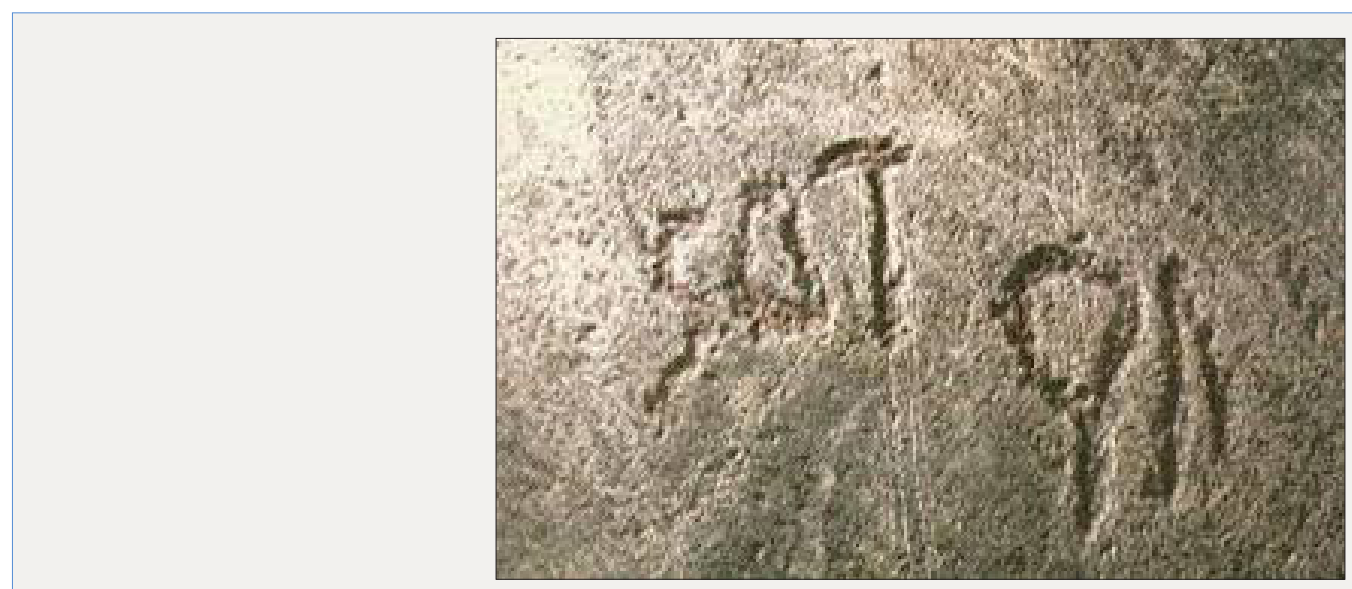

Figure 27:

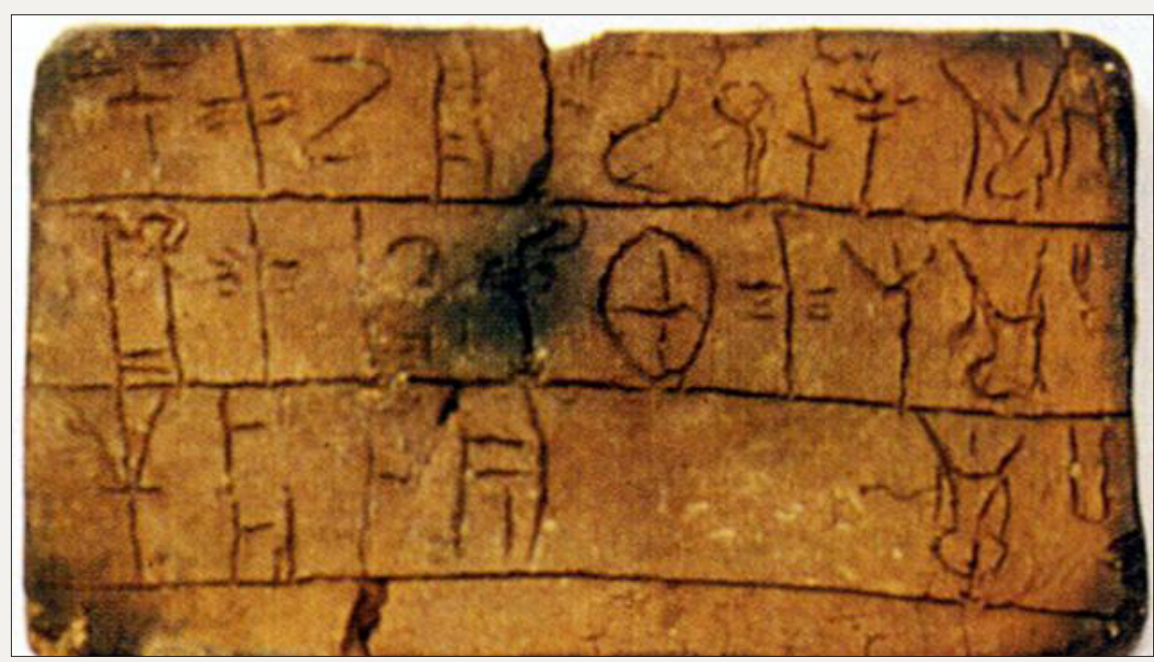

Figure 28:

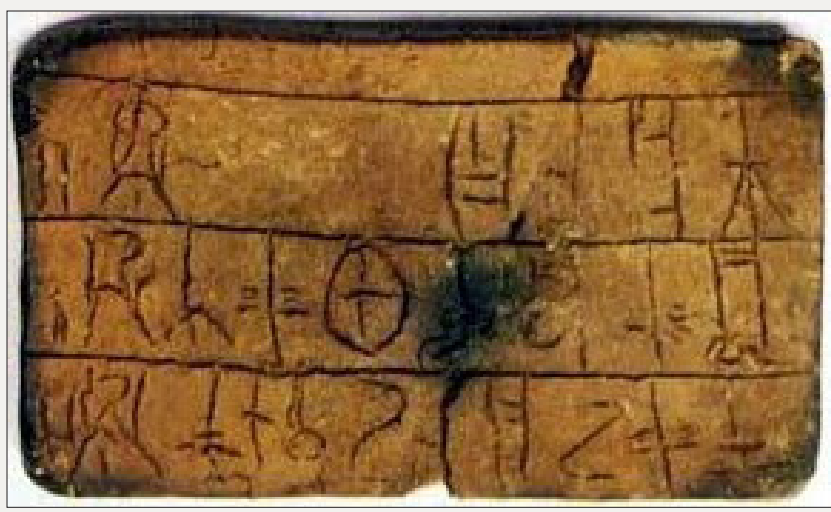

Figure 29: 


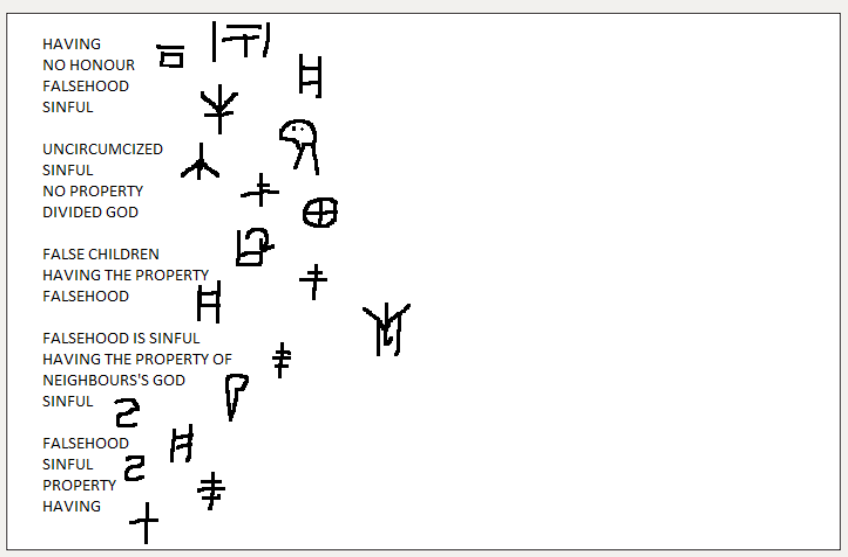

Figure 30:

Line5: do not covet property/children (?)/do not add properties of evil (Sabbath) (Figure 27-30). Right to left: don't have false gods. Do honor evil

\section{$8^{\text {th }}-$ Falsehood tablet}

Right to Left

\section{Royal Hebrew L226 Y DNA}

Table 1:

\begin{tabular}{|c|c|c|c|c|c|}
\hline $\begin{array}{l}\text { Genetic } \\
\text { Distance }\end{array}$ & Name & $\begin{array}{l}\text { Most Distant } \\
\text { Ancestor }\end{array}$ & $\begin{array}{c}\text { Y-DNA } \\
\text { Haplo-group }\end{array}$ & $\begin{array}{l}\text { Terminal } \\
\text { SNP }\end{array}$ & $\begin{array}{c}\text { Match } \\
\text { Date }\end{array}$ \\
\hline 0 & Mr. Pete Sutherland & Y-DNA37 FF & $\begin{array}{c}\text { Thomas Dan Sutherland } \\
\text { Sr., b. } 1872\end{array}$ & R-L21 & $3-19-2013$ \\
\hline 0 & Mr. David Albin Cameron & Y-DNA37 & & R-M269 & $2-18-2013$ \\
\hline 0 & Mr. Jeffrey Scott Long & Y-DNA37 & & $\mathrm{R}-\mathrm{L} 2$ & 02-09-2013 \\
\hline 0 & Mr. Symon James Windsor & Y-DNA37 & $\begin{array}{l}\text { William Head b } \\
\text { about } 1730\end{array}$ & R-L2 & $6-19-2012$ \\
\hline 0 & Mr. Richard Arthur Ainsworth & Y-DNA37 & $\begin{array}{l}\text { Joseph Ainsworth, b. } \\
1792 \text { CT, d. } 1873 \text { WI }\end{array}$ & R-P312 & 03-09-2012 \\
\hline 0 & Robert Emmet Moloney & Y-DNA67 & $\begin{array}{l}\text { Michael Moloney abt } \\
1800 \text { Galway?, Ireland }\end{array}$ & R-P312 & $2-22-2012$ \\
\hline 0 & Mr. Basil Ernest Richard Thornton & Y-DNA12 & & R-P312 & $10-12-2011$ \\
\hline 0 & Mr. Warburton & & Robert Warburton (b. 1828) & R-M269 & $7-18-2011$ \\
\hline 0 & Mr. James William David Wilson & Y-DNA67 & $\begin{array}{l}\text { James William David } \\
\text { Wilson }\end{array}$ & R-L21 & $5-21-2011$ \\
\hline 0 & Mr. karl oliver kessler & Y-DNA12 & & R-P312 & 02-09-2011 \\
\hline 0 & Mr. Jimmie Long & Y-DNA67 FF & $\begin{array}{l}\text { Thomas Long, } \\
\text { b. } 1717\end{array}$ & $\mathrm{R}-\mathrm{L} 2$ & $06-10-2010$ \\
\hline 0 & Mr. Ralph Alderson Averay & Y-DNA67 & $\begin{array}{l}\text { Robert Averay b.1635 } \\
\text { Witheridge, Devon }\end{array}$ & R-M269 & $5-20-2010$ \\
\hline 0 & Claxton & & & R-M269 & $3-30-2010$ \\
\hline 0 & James Long & Y-DNA37 & & R-P312 & $10-05-2009$ \\
\hline 0 & H.D. Lamberth & Y-DNA67 & $\begin{array}{l}\text { William Lamberth, } \\
\text { d. 1877, Abbeville, TX }\end{array}$ & R-U152 & $10-05-2009$ \\
\hline 0 & Ms. Johanne Marie Roselle Hart & Y-DNA67 & $\begin{array}{c}\text { Louis Hart, b. +/- 1799, d. } 1849 \\
\text { St-Anicet Q.C. Ca }\end{array}$ & R-L21 & $10-05-2009$ \\
\hline 0 & George Johnson & Y-DNA67 & Daniel Johnston $1788 \mathrm{NC}$ & R-M269 & $10-05-2009$ \\
\hline 0 & William Wallace Dickens & Y-DNA12 & & R-M269 & $10-05-2009$ \\
\hline
\end{tabular}




\begin{tabular}{|c|c|c|c|c|c|}
\hline 0 & Mr. Boltze & & $\begin{array}{c}\text { Andreas BOLTZE, } \\
1630-1690\end{array}$ & R-L2 & $10-05-2009$ \\
\hline 0 & Roger Thomas Long & Y-DNA37 & & R-L2 & $10-05-2009$ \\
\hline 0 & Mr. David Leslie Head & Y-DNA12 & $\begin{array}{l}\text { William Head } \\
1727-1800\end{array}$ & R-P312 & $10-05-2009$ \\
\hline 0 & Gregory Lessel Long & Y-DNA25 & & R-P311 & 10-05-2009 \\
\hline 1 & Ms. Morrissey & & $\begin{array}{c}\text { John William Morrissey b } \\
1839 \text { Boston }\end{array}$ & R-L226 & $5-27-2014$ \\
\hline 1 & Sullivan & & $\begin{array}{l}\text { Sullivan, b. 1905, Co. Cork, } \\
\text { father unknown }\end{array}$ & R-M269 & $3-28-2014$ \\
\hline 1 & Mr. Michael Thomas Laird & Y-DNA37 FF & John Laird b. 1765 & R-L513 & 01-09-2014 \\
\hline 1 & Mr. James Alan Turner & Y-DNA37 FF & $\begin{array}{l}\text { Samuel B. Turner b } \\
\text { 4-1856 NY d aft1900 PA }\end{array}$ & R-DF21 & $4-20-2013$ \\
\hline 1 & Mr. Ashmore & Y-DNA111 FF & $\begin{array}{l}\text { Daniel Dial Chandler, } \\
\text { b. 1783, d. 1843, Sumter, SC }\end{array}$ & R-DF21 & $04-02-2013$ \\
\hline 1 & Mr. Michael John O’Hearn Esq & Y-DNA111 FF & $\begin{array}{c}\text { Thomas Hern, } \\
\text { born circa } 1725\end{array}$ & R-L226 & 02-04-2013 \\
\hline 1 & Mr. Robert Louis Jennings & Y-DNA67 FF & $\begin{array}{l}\text { James Jennings. b. } \\
\text { ca } 1750 \text { d. } 1834\end{array}$ & R-L226 & $10-15-2012$ \\
\hline 1 & Peavey & & & R-L226 & $9-14-2012$ \\
\hline 1 & Mr. William Christopher Kane & Y-DNA111 & $\begin{array}{l}\text { William/John Kane, } \\
\text { b. About } 1785\end{array}$ & R-L513 & $2-15-2012$ \\
\hline 1 & Phyffe & & unknown & R-L226 & $1-31-2012$ \\
\hline 1 & William James Gleeson & Y-DNA37 & $\begin{array}{l}\text { Michael Gleeson, } \\
1831-1896\end{array}$ & R-L226 & $11-17-2010$ \\
\hline 1 & Mr. Douglas Hamilton Mackinnon & Y-DNA111 & Mackinnon & R-P312 & 8-23-2010 \\
\hline 1 & Mr. Ronald G Long & Y-DNA67 FF & $\begin{array}{l}\text { Thomas Long b. } \\
1717 \text { England }\end{array}$ & R-P311 & $8-23-2010$ \\
\hline 1 & George Ayres Lynn & Y-DNA67 FF & Ayres Linn (Dec 1855 - Mar 1918) & $\mathrm{R}-\mathrm{L} 21$ & 7-30-2010 \\
\hline 1 & Mr. John Paul Donahue & Y-DNA111 & $\begin{array}{l}\text { Lawrence Donahue, } \\
\text { b. abt. } 1825 \text { d. abt. } 1872\end{array}$ & R-L159 & $4-27-2010$ \\
\hline 1 & Mr. John Edward O’Brien & Y-DNA37 & $\begin{array}{l}\text { Daniel O'Brien,bc.1770, } \\
\text { r.Broadford,Co.Limerick,Ire }\end{array}$ & R-L226 & $3-25-2010$ \\
\hline 1 & Mr. Robert Gerard Mc Donnell & Y-DNA67 & $\begin{array}{c}\text { Alexander McDonnell } \\
1883 \text { - } 1951 \\
\end{array}$ & R-L226 & $10-19-2009$ \\
\hline 1 & Mr. Lawrence H Long & Y-DNA12 & & R-M269 & 10-05-2009 \\
\hline 1 & Mr. Paul Guzman Escalante & Y-DNA67 & $\begin{array}{l}\text { Juan de Escalante, } \\
\text { b.1680 and d. } 1775\end{array}$ & R-DF21 & $10-05-2009$ \\
\hline 1 & Mr. Justin Noel Long & Y-DNA67 & & $\mathrm{R}-\mathrm{Z} 12$ & $10-05-2009$ \\
\hline 1 & Mr. McPherson & & $\begin{array}{c}\text { John Macpherson b1745-/d1810 } \\
\text { Killean Argyll Scot }\end{array}$ & R-PF5236 & $10-05-2009$ \\
\hline 1 & Mr. James William O’Brien & Y-DNA12 & & R-M269 & $10-05-2009$ \\
\hline 1 & Julio Antonio Arévalo Aguirre & Y-DNA37 & Arévalo Buendia & R-L21 & 10-05-2009 \\
\hline 1 & David Albert Brown & Y-DNA67 FF & $\begin{array}{c}\text { James Riley Brown, } \\
1862 \text { - } 1927 \text { Dooly Co, Georgia }\end{array}$ & R-L226 & $10-05-2009$ \\
\hline 1 & Byrne & & British Isles & R-L21 & 10-05-2009 \\
\hline 1 & Mr. Gerald Francis Mc Carragher & Y-DNA37 & John Mc Carragher & R-L21 & 10-05-2009 \\
\hline 1 & Mr. Scott Alexander Mc Pherson & Y-DNA111 FF & $\begin{array}{c}\text { John Macpherson b1745 } \\
\text { Argyllshire, Scot>son Donald }\end{array}$ & R-PF5236 & $10-05-2009$ \\
\hline 1 & Mr. Peavy & & $\begin{array}{l}\text { Charles Peevy, } \\
\text { abt. } 1788 \text { - abt. } 1852\end{array}$ & R-L226 & $10-05-2009$ \\
\hline 1 & Harold McKinnon & Y-DNA111 & $\begin{array}{l}\text { Gregor MacKinnon, born 1749, } \\
\text { Skye, Scotland, died }\end{array}$ & R-PF5236 & $10-05-2009$ \\
\hline 1 & Peter Thomas Kennedy & Y-DNA67 & & R-L226 & 10-05-2009 \\
\hline
\end{tabular}


The RL226 is the royal Jewish Line. It went from Israel to the British Isles (Scotland, Wales, England and Ireland.) Machir brought it to France and the royal hose of Europe. There are some transplants in Montreal, Saint John NB, and Mexico according to FTDNA. The Hebrews brought with them the technology of the Egyptians in stone Henge. This is why we see the stone circles in Wales, Scotland, and south Ireland. The tribe of Manasseh brought the Pyramids to Mexico. There are also Hebrews in Germany and France. We expect this because Hugh capet was from Tongerun, Belgium. The royal Bourbons descend from the royal house of Israel. The line of David was known to have transferred to Spain. This is why we see L226 in Ireland (Mileisus) and in Mexico (Spaniards) (Figure 31\&32) and (Table 1).

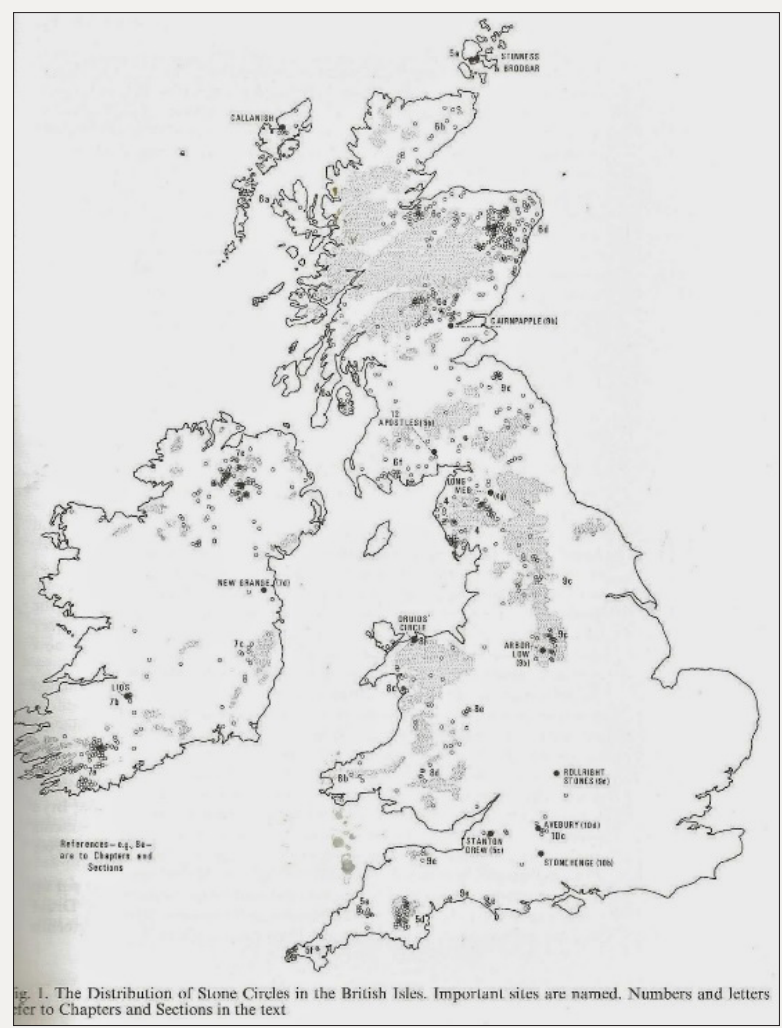

Figure 31:

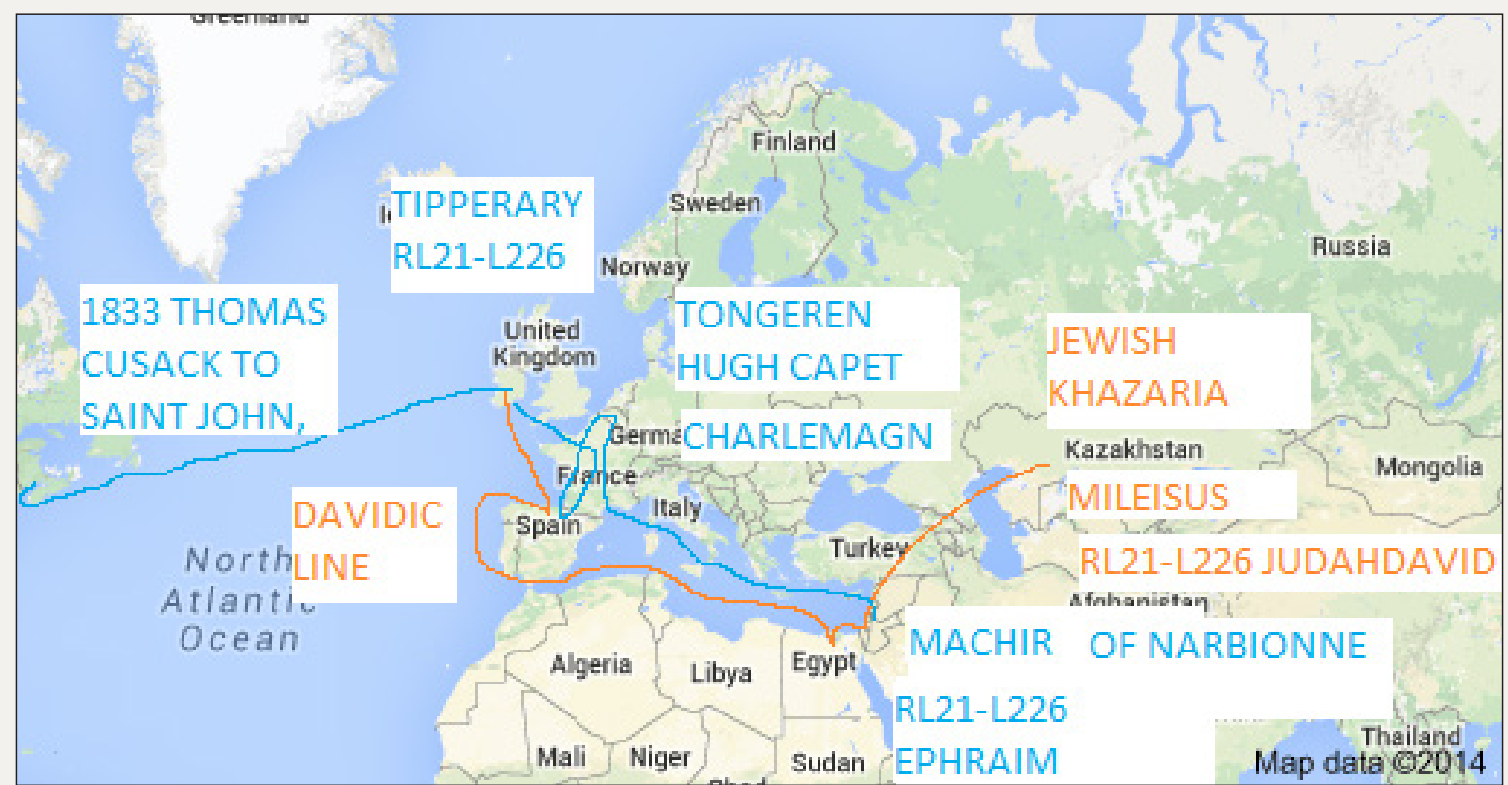

Figure 32: 


\section{Stone Henge}

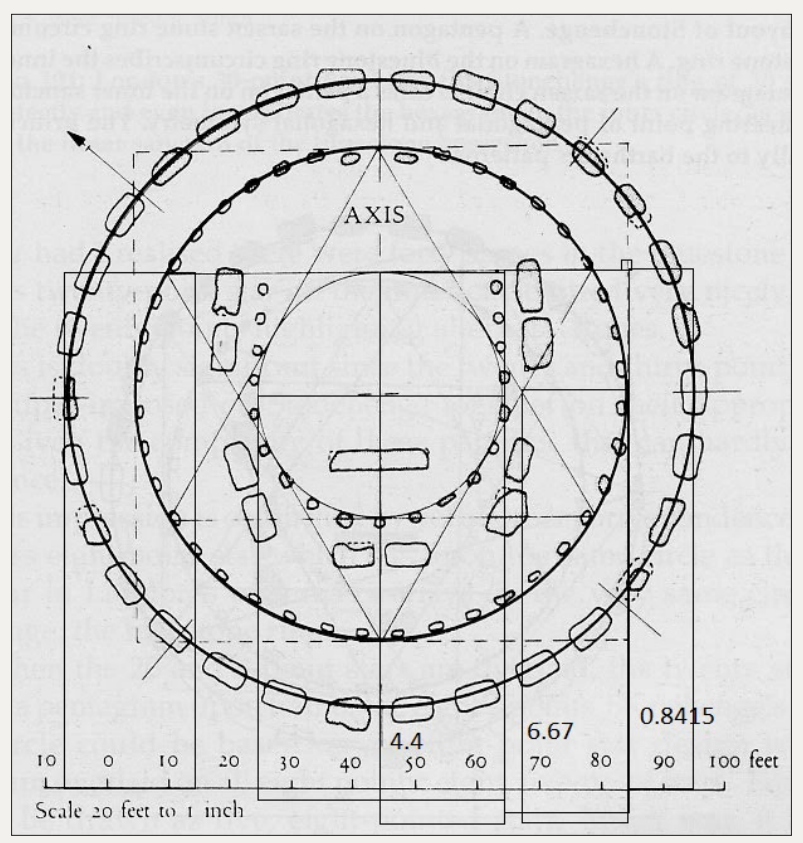

Figure 33: There is a picture of this star on the floor at the cathedral.

\section{Mass $=4.486$}

$\mathrm{G}=6.67$

$\operatorname{Sin} 1=\operatorname{Cos} 1=0.8415$
Stonehengeis the throne of god. (Figure 33)

There is a picture of this star on the floor at the cathedral.

RL21-L226 Irish Dalcassians is Israelite royal line (Figure 34).

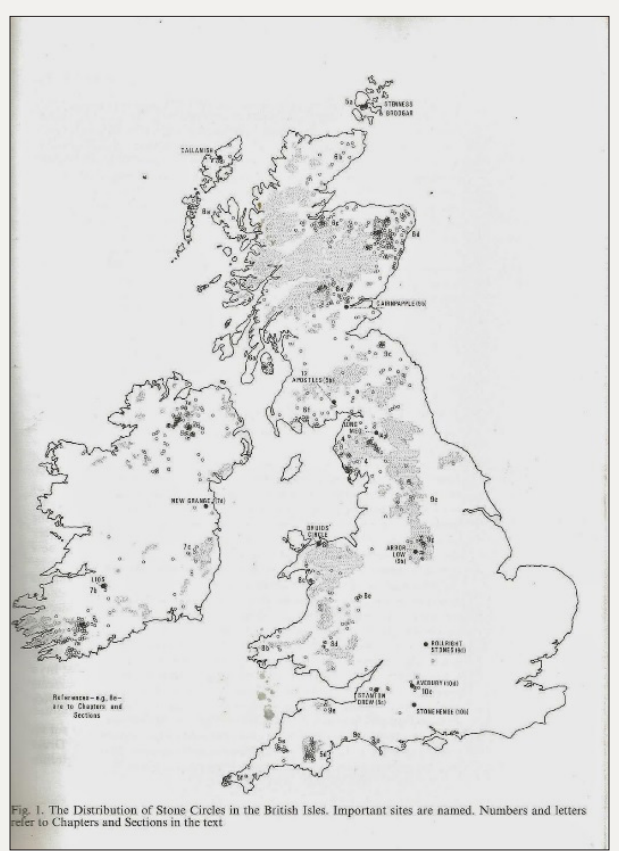

Figure 34: These stone circles were made by the Israelites who picked up the ideas in Egypt under Joseph. The 1226 follows this pattern. Also there are 1226 in Germany near Tongerun Belgium. Machir of Narbonne was an Israelite who founded the French throne.

These stone circles were made by the Israelites who picked up the ideas in Egypt under Joseph. The 1226 follows this pattern.
Also there are 1226 in Germany near Tongerun Belgium. Machir of Narbonne was an Israelite who founded the French throne. 


\section{The coyness were coyness (Israelite priests)}

The people who built the Pyramids also built Stonehenge. Genetic genealogy is showing that the Scots were Israelites. Stonehenge also embodies the golden mean in the ration of the stone circles 2, 2, 1-the same as the Egyptian Pyramid bases.
The Longitude of Stonehenge is 1.8 degrees and the Latitude is 51.17 degrees. The slope on the Great Pyramid is 51.5 degrees. That is a 31.8 (Human Perception $=31.8 \mathrm{~Hz})$ by $21.17\left(21.17^{\wedge} 2=4.482 \sim\right.$ Mass of Universe=4.486) 18 is the sum of the Potential Energy plus the Kinetic Energy (Figure 35). Reference: Ancient Measurement of the Circumference of the Earth.

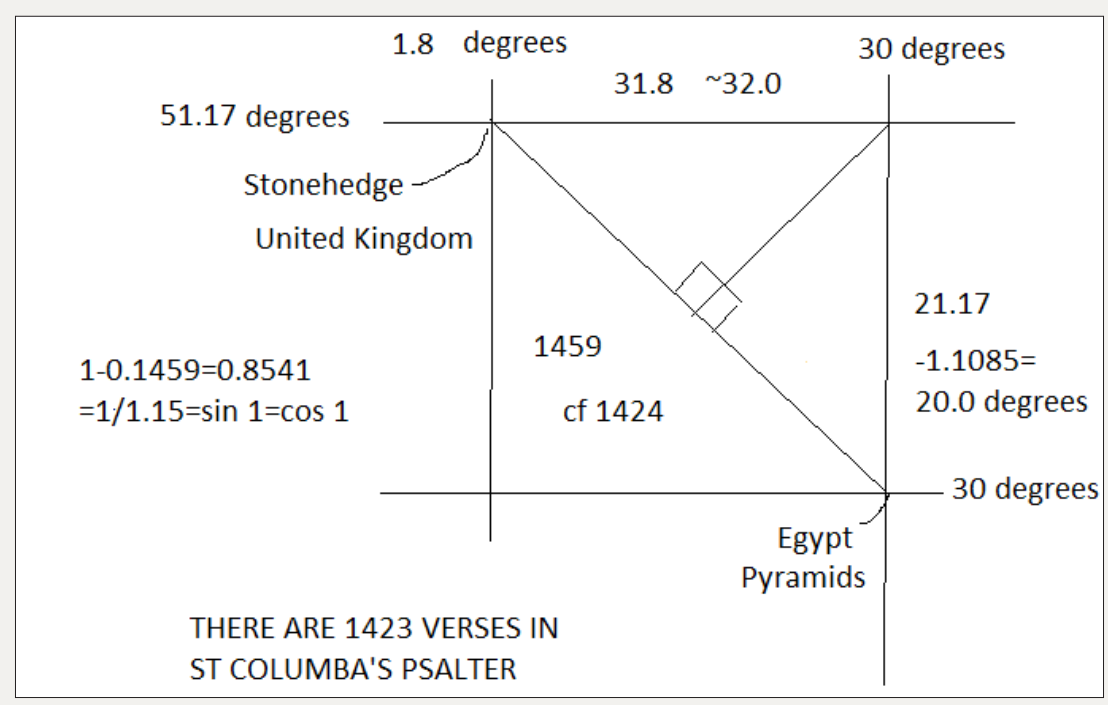

Figure 35: These stone circles were made by the Israelites who picked up the ideas in Egypt under Joseph. The 1226 follows this pattern. Also there are 1226 in Germany near Tongerun Belgium. Machir of Narbonne was an Israelite who founded the French throne.

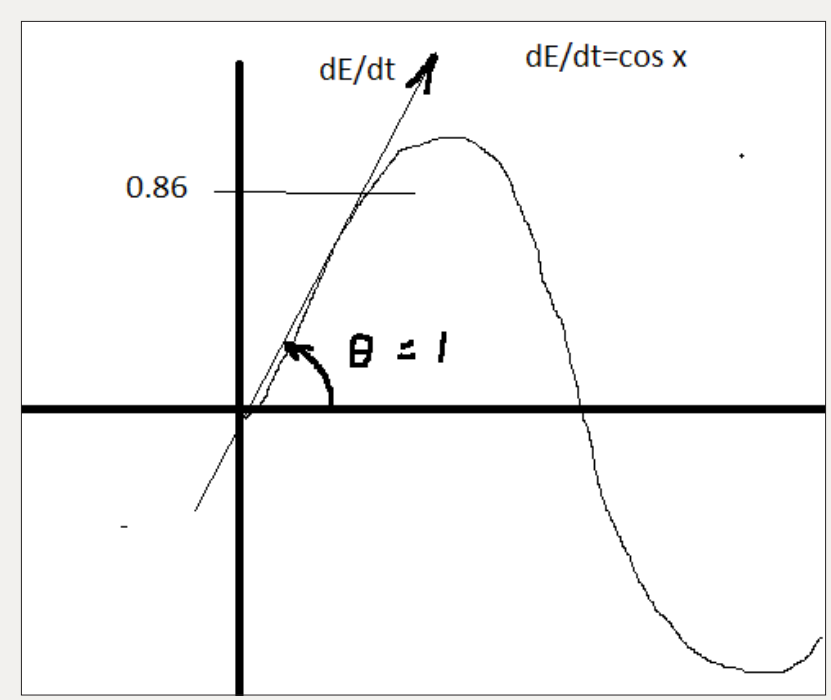

Figure 36: These stone circles were made by the Israelites who picked up the ideas in Egypt under Joseph. The 1226 follows this pattern. Also there are 1226 in Germany near Tongerun Belgium. Machir of Narbonne was an Israelite who founded the French throne.

Ancient metrological tables state that the Philetairic or Ptolemaic royal cubit (which is the Babylonian-Egyptian royal cubit according to Boeckh's terminology) is $9 / 5$ of the Roman foot, so that the figure of Eratosthenes comes to be the usual figure of 75 Roman miles to the degree. But several authors of the Roman period mention a degree of 700 stadia. This degree value should not be confused with that of Eratosthenes and is based on a stadion of 300 royal cubits of the Pharaonic period; these two points have been made by Letronne. I have reported that the correct Egyptian royal cubit was $525 \mathrm{~mm}$, but it was at times computed as $524 \mathrm{~mm}$ and at times as $\mathrm{mm}$, assuming a cubit of $525 \mathrm{~mm}$. the degree would be 110,250 and assuming a cubit of $526.3 \mathrm{~mm}$. It would be 110 , it is easy to see why the figure of 700 stadia to the degree was chosen: it well fits the pattern of septenary reckoning in the Egyptian royal 
cubit. But the length of the degree at latitude $30^{\circ}$, the latitude of the pyramids and of the beginning of the Delta, is $110,849 \mathrm{~mm}$. At the southern limit of the country, this is at latitude $24^{\circ}$, the degree $110,750 \mathrm{~m}$. Hence, it seems that in Egypt, for the sake of a convenient reckoning there was adopted a value that it slightly in defect. Perhaps the figure was chosen because it was convenient and the methods of observation used did not allow determining any error in it. This figure may have had great importance in convincing the ancients that the degree was shorter in Egypt than at latitude $36^{\circ}$ (Figure 36). Cosine $\mathrm{x}$ is the universal equation. Stonehenge is the "throne of God." The Pyramids of Egypt are sqrt 1424=0.858 $=0.86$ away from the Throne of God.

\section{From the Christian community bible}

There, in heaven, was a throne and one sitting on it. He who sat there looked like jasper and carnelian and round the throne was a rainbow resembling an emerald. In a circle around the throne are twenty-four thrones and seated on these are twenty-elders, dressed in white clothes, with golden crowns on their heads. Flashes of lightning come forth from the throne, with voices and thunderclaps. Seven flaming torches burn before the throne; these are the seven spirits of God. Before the throne there is a platform, transparent like crystal. Around and beside the throne stand four living creatures, full of eyes, both in front and behind (Figure 37).

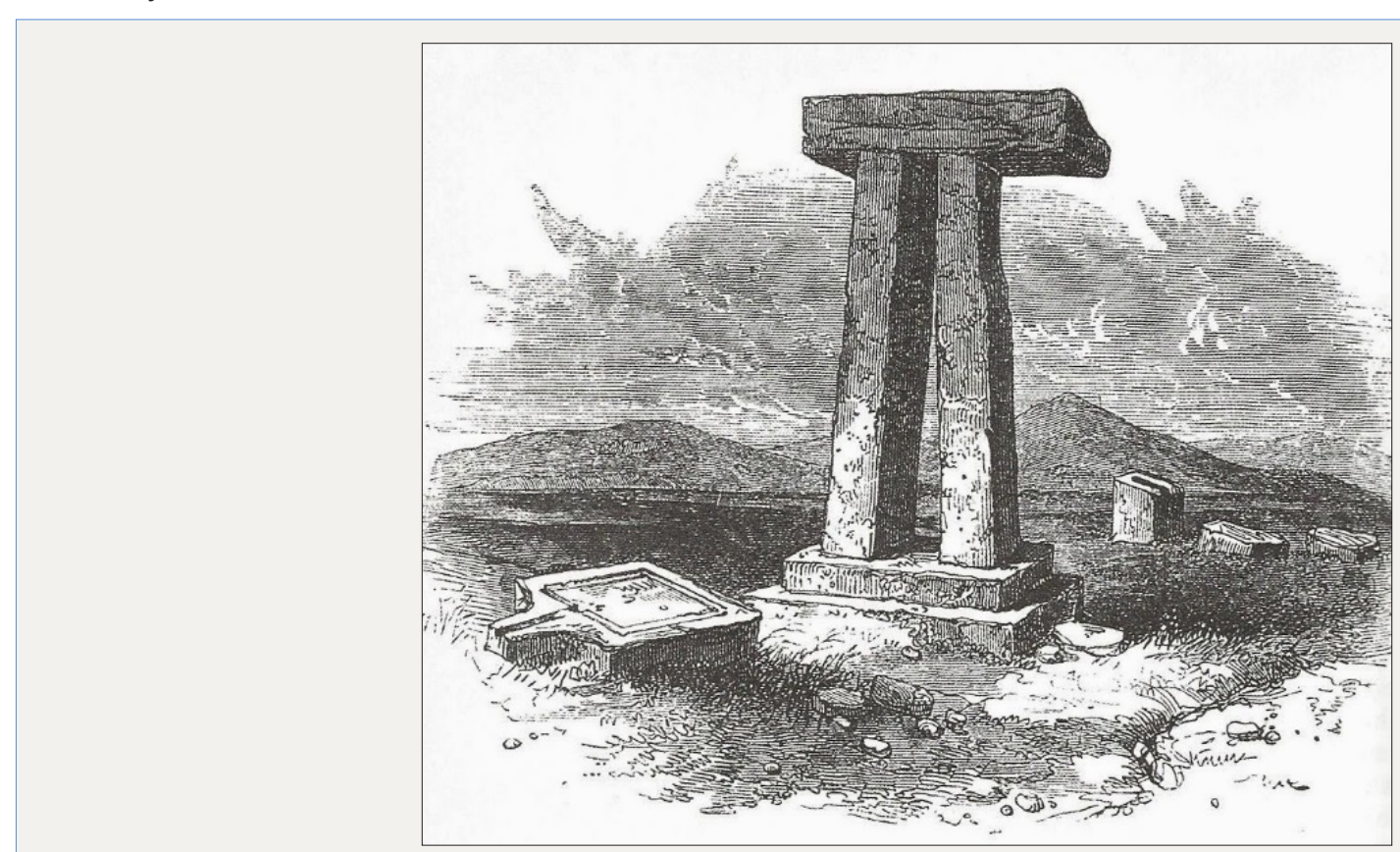

Figure 37: The stone lintels for the Greek letter pi=3.14 which figures into the universal energy equation

The Stone Lintels For The Greek Letter Pi=3.14 Which Figures Into The Universal Energy Equation.

$5 \times 3.14=15.70,1-0.1570=0.8430=\operatorname{Sin} 1=\operatorname{Cos} 1$

18 Interior stones $=$ Total energy $=$ P.E $+K . E=18$

\section{From Stonehenge complete chippendale C, cornell U press, 1983}

The individual stones at Stonehenge are $10.5 \times 3.5 \times 2.75$. That is $42 / 4 \times 14 / 4 \times 11 / 4$

\section{$\mathrm{dM} / \mathrm{dt}^{*} \mathrm{M}$ rho/Erho=1/G, 2x³/4=1/.666 (Revelation 13).}

$42=$ Pi-e=cuz; $14-100=86=\sin 1=\cos 1 ; 9=c^{\wedge} 2$ all physical constants of the universe. The stones are 13.5 feet high. 13.5$100=86.6=\sin 1=\cos 1$.

There are 30 stones on the perimeter. $30 / 4=7.5,1 / 7.5=0.1334$ this is distance $\mathrm{s}$ in Physics. The Heel Stone is almost 85 feet outside the causeway $(\sin 1=\cos 1=0.8415)$. The heel stone is almost 16 feet high (0.1585-1=0.8415) (Figure 38).

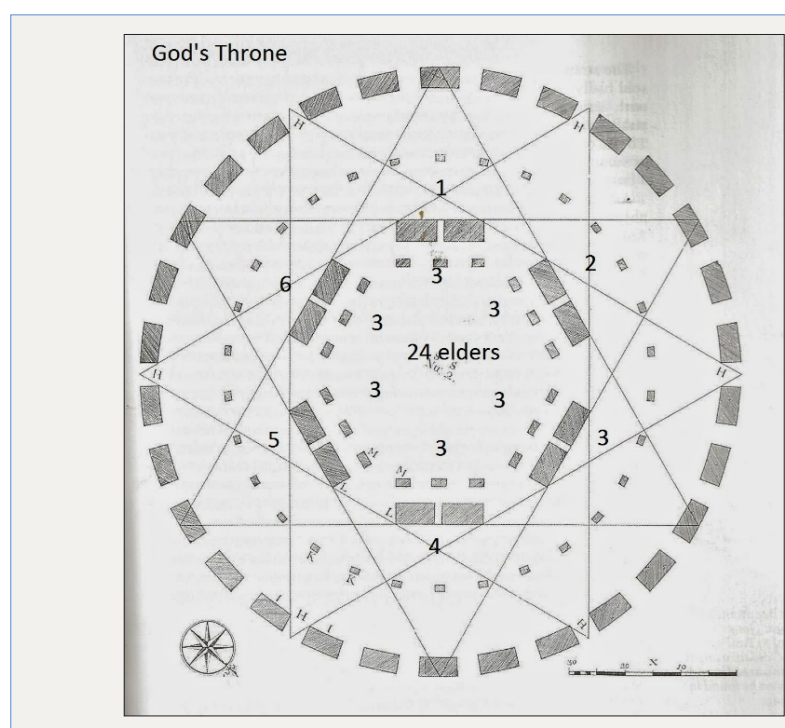

Figure 38: From stone hedge complete Chippendale c, Cornell u press 1983 


\section{From Stonehenge complete chippendale C, cornell U press 1983}

Note that several universal constants are embodied in the geometry including:

The relative radius measures are $45-65=20 ; 65-85=20 ; 85$ $95=10$ or $2,2,1$. This is the same as the bases of the Great Pyramids in Egypt. The Mass of the universe; the gravitational constant; the meeting of $\sin 1$ radian=cos 1 radian=0.8415. Of course, the Winter Solstice- final date of December 21 is embodied as well. JESUS came at the bottom of the parabola or where the derivative of the C.U.E.E. $=0(2 t-1=0)$ each division of the $\mathrm{x}$ axis is 1000 years per decimal Jesus was born in $3 \mathrm{BC}$ at the base of the parabola.

The stone circles of the British Isles were mostly constructed between 2500-1600BC. The Pyramids in Egypt, from 2037-400BC. Moses left Egypt in 1800BC. So the stone circles predate the pyramids of Egypt. But Stonehenge in the form of its inner circle, which relate it to the Egyptian Pyramids, was constructed in around 200-1550BC. So, that is only 37 years after the Pyramids were built we see the golden mean in Stonehenge (Figure 39).

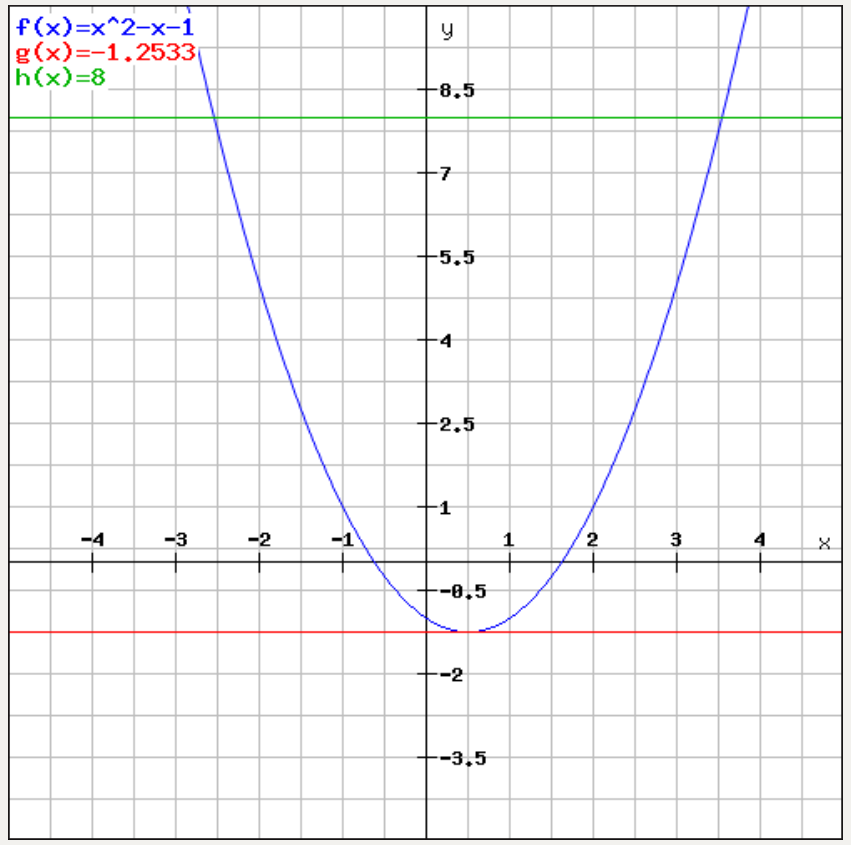

Figure 39:

\section{St Columbus Psalter}

I double checked the number of verses in the Columba Psalter. It is actuality $1276.1276 / 2=638,1 / 638=0.1567=0.8433 \sin 1=-$ $\cos 1=0.8415$ Pretty close for $600 \mathrm{AD}$. The $638^{\text {th }}$ verse lies in Psalm 71(70). It is: For you oh Lord, has been my hope, my trust, 0 God from my youth. This then is the key:

1. For my enemies speak ill of me; awaiting my death they set plans.

2. They say, "God has forsaken him; let us pursue and seize him, for no one will rescue him."

3. God, be not far from me; my God, make haste to help me!

4. Let my accusers be destroyed in shame; let those who seek my ruin be covered with disgrace and scorn.

5. Then I may trust in you and praise you.

6. My lips will proclaim your intervention and tell of your salvation all day, little though it is what I can understand.

7. I will come to your strength, O Lord, and announce your justice, yours alone.
8. You have taught me from my youth and until now I proclaim your marvels.

9. When I grow old and gray, do not leave me, 0 God; give me time to declare your might, your power to all generations to come.

10. Your justice, O God, reaches to heaven; you have done great things. Who is like you, 0 God?

11. Many have been my hardships and misery, but once more you come to revive me; from the depths of the earth you will bring me up again.

12. You will restore me and comfort me again.

13. I will praise you with the harp, for your faithfulness, 0 my God; I will sing your praise with the lyre, 0 Holy One of Israel.

14. My lips will rejoice, and my soul, too, which you have rescued.

15. I will recall your intervention the whole day long, "Yes, those who sought to do me harm have been confused and put to shame." 
The Key tothe gold box march 10, 2014 Osama bin laden's birthday great monarch.

Psalm 30:10-105: 13/2=67.5

Psalm 67(66)

All the nations will know you.

May God be gracious and bless us;

May he let his face shine upon us,

That your way be known on earth

And your salvation among the nations.

May the peoples praise you, 0 God,

May all the peoples praise you!

May the countries be glad and sing for joy,

For you rule the peoples with justice
And guide the nations of the world.

May the peoples praise you, O God?

May all the peoples praise you!

The land has given its harvest;

God, our God, has blessed us.

May God bless us and be revered,

To the very ends of the earth.

\section{St columba's psalter and the physical constants of the universe}

The shape of this decoration is the in function meeting pi further indicating that the ancients knew about how the universe was made. If the ancients thought pi was $22 / 7$, then that pretty dam close to 0.14286 or 1423 . Maybe someone could recount the number of verses from psalm 30:10 to 105:13? We are looking for 1428 or 9 (Figure 40).

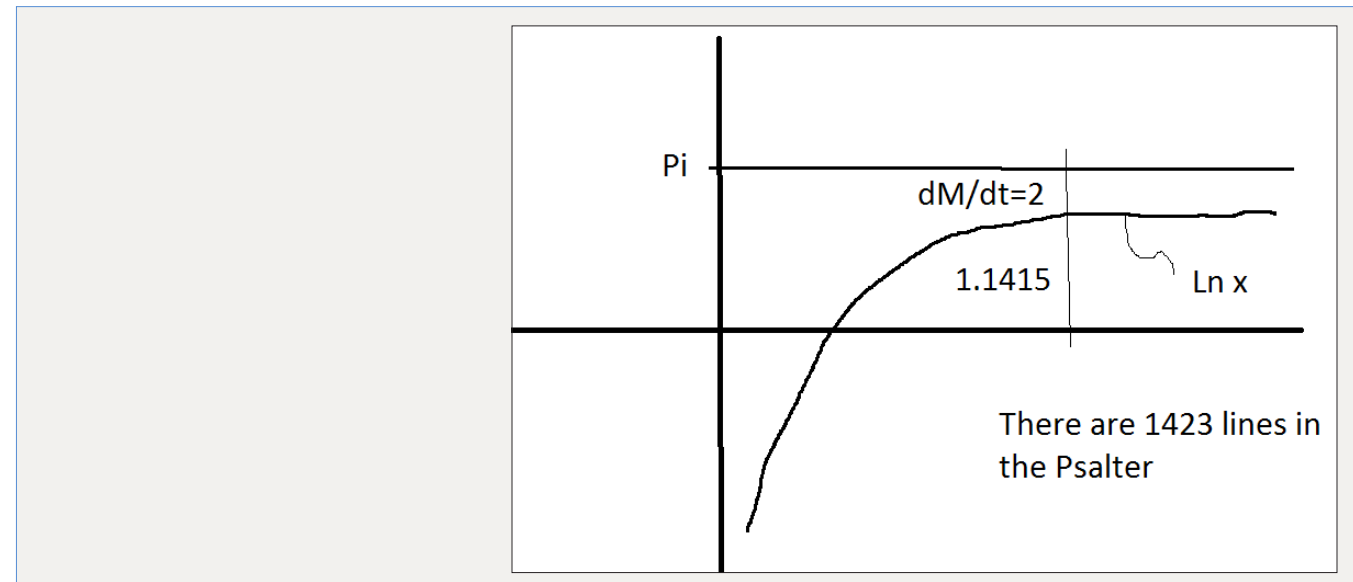

Figure 40:

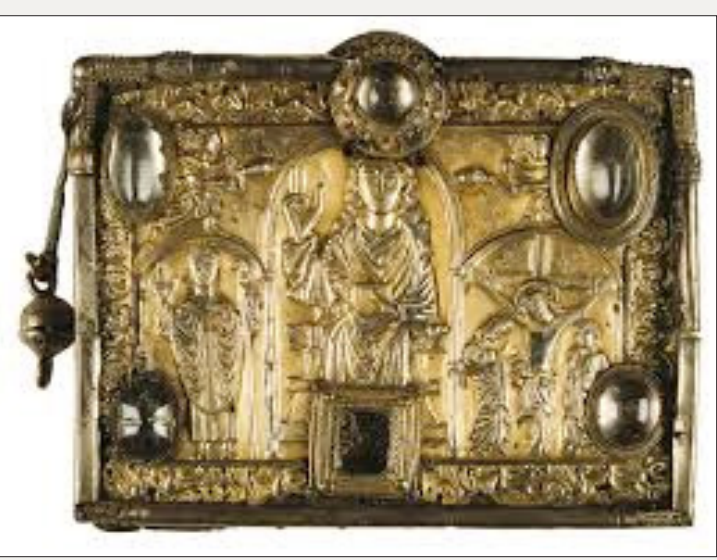

Figure 41:

The decoration of the Catha is limited to the initial letter of each Psalm. Each initial is in black ink and is larger than the main text. They are decorated with trumpet, spiral and guilloche patterns and are often outlined with orange dots. These patterns are not merely appended to the letters or used to fill spaces. They instead distort the shape of the letters themselves. The letters following the enlarged initials gradually reduce in size until they reach the same size as the main text. Although the motifs of the Cathach 
decoration are not similar to decorations in later manuscripts, such as the Book of Durrow (which followed the Cathach by as many as seventy years), the ideas of decoration which distorts the shape of the letters and the diminution of initial letters are ideas which are worked out in great detail in later Insular art (Figure 41).

Here's what the ancients knew that no other physics besides me knows:

\section{$1 / \mathrm{G}=\mathrm{MRHO} / \mathrm{E}$ RHO $*(\mathrm{DM} / \mathrm{DT})$ \\ $1 / 6.66=3 / 4 * 2$}

666=EVIL EVIL EVIL

Now, $1 / 81=0.12345679$

$8=\mathrm{E}$

$(8+1 / 7)-\mathrm{Pi}=8.1429-22 / 7=5$

1,2,3,4,5,6=Evil,7=Good (5 loaves two fishes/4 loaves two fishes)

Now the gold box that holds the Psalter of st Columba Is 2X8X9

$\mathrm{E}=\mathrm{Mc}^{\wedge} 2$ (EINSTEIN???)

$(2)(9)=18$

$\mathrm{E}=8$

$18-8=10$
$10=\mathrm{P} . \mathrm{E}=\mathrm{mgh}$

$10 / 6.66=(2)(3 / 4)$

They knew a lot more than we thought because the concepts of decimals were in their mind. They may have even had a hexadecimal system?

$8 / 10=0.125$

$6 * 0.125=0.75=3 / 4=75=\#$ of psalms $105-30=75$

$75=150$ Psalms $/ 2$

The ancients also must have know the equation of a circle

$\mathrm{X}^{\wedge} 2+\mathrm{Y}^{\wedge} 2=\mathrm{R}^{\wedge} 2$

$2 X^{\wedge} 2=1$

let the area of a circle $=1$

$2 X^{\wedge} 3 / 3=1$

$3 / 2=X^{\wedge} 3$

$\mathrm{X}=1.1446$

$1-1.1446=0.1446$

0.1446-23=1423 \# oflines in psalms 30:10-105:13

Verse $10+$ Verse $13=26$

1446-23=1423 (Figure 42)

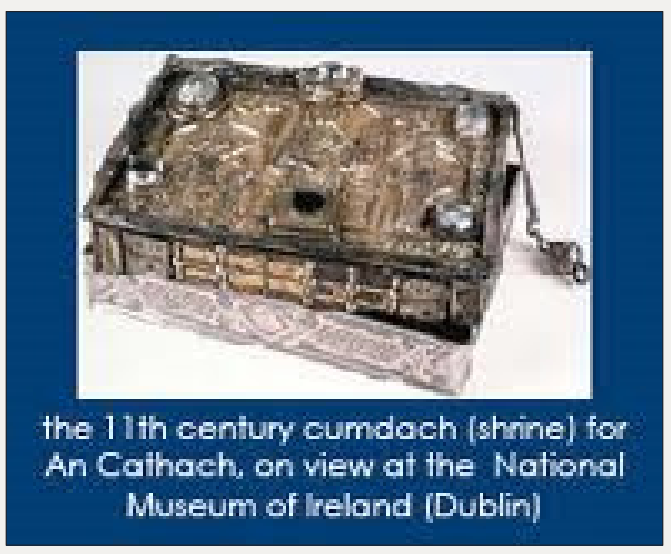

Figure 42: The pearl is the birth stone of Gemni June $6=66=$ Evil.

The diamond is the birth stone of aries April $5=45=$ God

The opal is October $=8=$ Energy

The emerald is May=Taurus

If there are 3 Opals, 2 Emeralds, and 1 Peral

$1 / 6.66=3 / 4 * 2$

The box is $2 \times 8 \times 9$

$2 \mathrm{X} 3^{\wedge} 2 \mathrm{X}(4 \mathrm{X} 2)$

So we have $1,2,3$ and2,3,4
$1=(3 * 3) * 2 /(4 * 2)$

$1=2.25$

2.25-1=1.25 = minimum of energy equation $\mathrm{X}^{\wedge} 2-\mathrm{X}-1,2 \mathrm{X}-1=0$, $\mathrm{X}=1 / 2,1 / 2^{\wedge} 2-1 / 2-1=-1.25$.

The specially made cumdach or book shrine is in the National Museum of Ireland. The initial work on the case was done between 1072 and 1098 at Kells, but a new main face was added in the 14th century with a large seated Christ in Majesty flanked by scenes of the Crucifixion and saints in gilt repoussé (NMI R2835, $25.1 \mathrm{~cm}$ wide). This was done by Cathbharr ÓD, chief of the Donnells 0 
and Domhnall Mag Robhartaigh, the Abbot of Kells. The shrine cover consists of a brass box measuring 9 inches long, 8 inches wide and 2 inches thick. The top is heavily decorated with silver, crystals, pearls and other precious stones. It shows an image of the Crucifixion and an image of St Colm Cille.

A Cathach is attributed to Saint Columba (known in Ireland as Columcille) who died in 597. It's said that a divine light allowed him to make a copy of a Psalter owned by his teacher, St. Finnian. A dispute over the ownership of Columba's copy followed, which led to the Battle of Cúl Dreimhne in 561. The book ended up in the possession of the O'Donnell clan of Co. Donegal, who carried the book as a battle talisman. Columba was blamed for the war and threatened with excommunication. Instead, he was exiled to the island of Iona, off the coast of Scotland. There he founded the monastery of Iona, which became an important center for learning and missionary work and which (much later) produced the Book of Kells.

\section{Conclusion}

We see that the Egyptian mathematic spread around the world through the Hebrews. (c) (i) Creative Commons Attribution 4.0

For possible submissions Click Here Submit Article

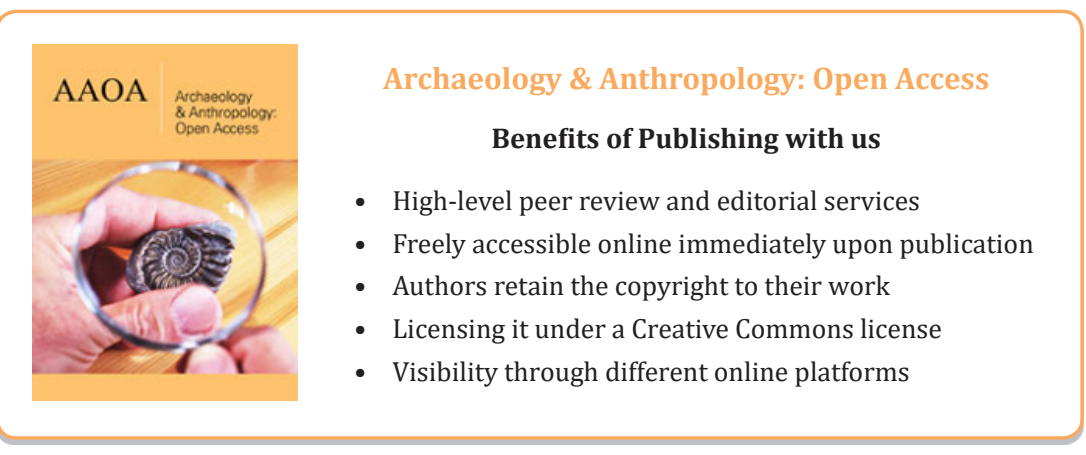

